\title{
Contractual Communication
}

Lawrence B. Solum

Georgetown University Law Center, Ibs32@law.georgetown.edu

This paper can be downloaded free of charge from:

https://scholarship.law.georgetown.edu/facpub/2208

Harvard Law Review Forum, Vol. 133, Pp. 23, November 8, 2019.

This open-access article is brought to you by the Georgetown Law Library. Posted with permission of the author. Follow this and additional works at: https://scholarship.law.georgetown.edu/facpub

Part of the Contracts Commons, and the Law and Philosophy Commons 


\title{
CONTRACTUAL COMMUNICATION ${ }^{\dagger}$
}

\author{
Lawrence B. Solum* \\ INTRODUCTION
}

In Pseudo-Contract and Shared Meaning Analysis, ${ }^{1}$ Professors Robin Bradley Kar and Margaret Jane Radin develop an important theory of the nature of contract that draws on Paul Grice's influential theory of meaning. ${ }^{2}$ That theory has significant implications for contract doctrine, especially for questions about the enforceability of socalled "contracts of adhesion" in particular and for "boilerplate" in general. But at the most fundamental level, Kar and Radin's work is about the nature of contractual communication. They answer the question: How do contracts mean? Their answer proposes a theoretical structure, which they name "Shared Meaning Analysis."3 This Response focuses on "contractual communication"4: it interrogates the philosophical and linguistic presuppositions of Shared Meaning Analysis and offers, in embryonic form, a rival view.

Shared Meaning Analysis begins with the idea that "meaning" can be shared. In the particular context of contractual communication, meaning is something that can be shared by the parties to a contract, but the idea of shared meaning is quite general: when a speaker successfully conveys communicated content to a listener, meaning is shared. Shared meaning arises in mundane contexts, like a conversation about the weather, and in legal contexts, including communication via constitutions, statutes, rules, regulations, treaties, judicial opinions, trusts, wills, and contracts.

\footnotetext{
$\dagger$ Responding to Robin Bradley Kar \& Margaret Jane Radin, Pseudo-Contract and Shared Meaning Analysis, I32 HARV. L. REV. I 35 (2019).

* Carmack Waterhouse Professor of Law, Georgetown University Law Center. This Response is dedicated to Peter Tiersma, my former colleague who passed from this earth long before his time. On many of the topics discussed in this Response, Peter got there first. See A Tribute to Peter $M$. Tiersma, LOYOLA L. SCH., https://petertiersma.lls.edu [https://perma.cc/K 3 UR-4QQR]. I am grateful to Brian Bix, Enrique Guerra-Pujol, Mitu Gulati, Tal Kastner, Dennis Patterson, Brian Slocum, and the editors of the Harvard Law Review for many helpful comments, criticisms, and suggestions.

1 Robin Bradley Kar \& Margaret Jane Radin, Pseudo-Contract and Shared Meaning Analysis, I32 HARV. L. REV. II35 (20I9).

2 Id. at I I44-56. See generally PAUl Grice, Studies IN THE WAY OF WORDS (I989) (collecting many of Grice's most important papers on the philosophy of language).

3 Kar \& Radin, supra note I, at II $42^{2}-43$. The capitalization of "Shared Meaning Analysis" conveys that I am using this phrase as a proper name for Kar and Radin's theory. I use this same convention to name other theoretical positions — for example "Public Meaning Originalism" — in the discussion that follows.

4 The idea of a theory of contractual communication is sometimes raised by legal scholars. See, e.g., Peter Goodrich, Habermas and the Postal Rule, I7 CARDOZO L. REV. I457, I467 (I996) (raising the possibility of "a general theory of contractual communication").
} 
Take the constitutional context as an example. When a constitutional provision is drafted (for example, by Gouverneur Morris at the Philadelphia Convention), and the drafter's communicative intentions are successfully conveyed to the other Framers, the members of the ratifying conventions, the public at large, and the officials who implement the constitutional text, meaning is shared. ${ }^{5}$ The meaning identified by constitutional theorists as "original public meaning" is a kind of shared meaning. ${ }^{6}$ Similarly, if the drafters of a statute successfully convey the same "plain meaning" (communicative content) to the relevant intended readerships (including judges, lawyers, and those subject to the statute's provisions), then the text of the statute will have a plain meaning.

But just as communication can succeed in the creation of shared meaning, it can also fail. Communication can misfire for a host of reasons. One such reason is illustrated by the existence of what are called "terms of art" or "technical language." Later in this Response, for instance, I will use terms like "implicature," "impliciture," and "presupposition." The first two of these terms are not used in ordinary English, but they do have precise meanings in the philosophy of language and theoretical linguistics. The third term, "presupposition," does have an ordinary meaning, but it has a more precise meaning when it is used by professional philosophers and scholars of linguistics. When the author of a text uses a technical term, but the reader doesn't know what it means, then communication fails in a way that the reader can recognize. But when an author uses a word or phrase in a technical sense and the reader understands that term in its ordinary sense, communication may fail without the reader's knowledge. In either case, we can say that the communication "misfires." And "misfire" is itself a technical term used to describe such failures of communication.

There are numerous other reasons that the communicative content of a text can fail to produce shared meaning. When installing software downloaded from the Internet, we are frequently asked to click a link that says something like "I agree" while given the option to click another link that takes one to the full text of the software license. If we fail to click through, read, and comprehend the text of the agreement, clicking the "I agree" link does not create shared meaning. In the case of such clickwrap agreements, it seems likely that fully shared meaning is very rare indeed.

\footnotetext{
5 Here is Kar and Radin's initial formulation of their notion of shared meaning: "We . . . define the 'shared meaning' of a contract as the meaning parties produce and agree to during contract formation that is most consistent with the presupposition that both were using language cooperatively to form a contract." Kar \& Radin, supra note I, at I I43.

6 Original public meaning is actually shared meaning only if it is successfully communicated. If constitutional communication misfires, then the meaning intended by the drafter of a constitutional provision can diverge from the meaning grasped by the public.
} 
Communication can also fail in another way. An officer can order a subordinate into battle and be disobeyed. I can request extra salsa at a restaurant, but the wait staff might ignore my request. A contracting party can make an offer that is rejected. In cases like these, a "speech act" (more on this concept below ${ }^{7}$ ) fails to gain what we can call "uptake." This is distinct from a failure of understanding: misunderstanding an order is one thing, but disobedience is quite another. The word "uptake" refers to the success or failure of a speech act: when a speech act succeeds, it gets "uptake."

Some communication is cooperative. We might say that shared meaning is the goal of cooperative communication. Some communication is noncooperative or "strategic." For example, the drafter of legal text (such as, a constitutional provision, statute, treaty, or contract) might want to communicate different messages to different readers. Thus, a clever drafter might deliberately try to write a statute that conveys one message when it is read by staffers and legislators but can convey a different message when it is read by judges and lawyers in the adjudicative process. This kind of strategic communication involves "speaking out of both sides of your mouth," deliberately creating meanings that are not shared by all of the intended readers of the text. I will use the phrase "unshared meaning" to refer to cases in which the content communicated by a legal text is not shared by those who are intended to read or to be affected by the text. ${ }^{8}$

In this Response, I will investigate the foundations of both shared and unshared meaning in legal communication. Part I takes a step back from contractual communication and offers a preliminary sketch of a general model of legal communication; the sketch draws on speech act theory and the work of Paul Grice, extending and modifying many of the insights developed by Kar and Radin. Part II turns to contractual communication, differentiating distinct "situations of contractual communication" and interrogating Kar and Radin's Shared Meaning Analysis. Part III interrogates Kar and Radin's distinction between "contract" and "pseudo-contract." The conclusion of the Response briefly reflects on the significance of Kar and Radin's project.

\section{A Preliminary Sketch of a General Model OF LEGAL COMMUNICATION}

Before we plunge into Kar and Radin's account of contractual communication, let us take a step back to consider legal communication more generally in two steps. The first step lays out some basic ideas about communication in general. The second step examines some of the ways in which legal communication involves special considerations.

\footnotetext{
7 See infra section I.A.4, pp. 32-34.

8 See infra section I.B.3(c), pp. 43-45.
} 


\section{A. Step One: Communication in General}

Before we can understand legal communication, we need some basic tools for understanding communication in general. Like Kar and Radin, I will begin with the powerful and influential work of Paul Grice and then consider the role of semantics and pragmatics before turning to Grice's famous maxims.

I. The Neo-Gricean Model of Communication. - The core of Grice's account of meaning is the idea of speaker's meaning. Although Kar and Radin focus on Grice's maxims of conversation, the maxims are not the key to understanding Grice's view. Instead, Grice's most fundamental idea involves what we can call communicative intentions. The speaker's meaning of an utterance is the meaning that the speaker intends to convey to the listener via the listener's recognition of the speaker's communicative intentions.

Notice that Grice's model involves a "reflexive intention." As Professors Kent Bach and Robert Harnish put it, "a reflexive intention is an intention that is intended to be recognized as intended to be recognized." 9 Authors intend for their intentions to be recognized: the author's meaning of a text is this intended meaning.

As Kar and Radin observe, Grice distinguishes speaker's meaning from sentence meaning. ${ }^{10}$ The sentence meaning of an utterance or text is very similar to the idea of "literal meaning" that is more familiar to lawyers. Sentence meaning is acontextual; it is the meaning of the words independent of the context of utterance. Sentence meaning is possible because words and phrases have conventional semantic meanings and because of the conventions of syntax that we sometimes call "rules of grammar and punctuation."

Before we go any further, we should note that the word "meaning" is ambiguous. ${ }^{11}$ When we talk about the "meaning" of a legally operative text, we might be referring to the effect of the text, the purpose for which the text was written, or the content communicated by the contextualized linguistic meaning of the text — and there are other meanings of "meaning." In the discussion that follows, the word "meaning" and the expression "shared meaning" represent the communicative

\footnotetext{
9 Kent Bach \& Robert M. HARnish, Linguistic Communication And SpeEch ACTS, at xiv-xv (I979); see also François Recanati, On Defining Communicative Intentions, I MIND \& LANGUAGE 2 I3, 2 I4-I5 (I 986) (quoting BACH \& HARNISH, supra, at xiv-xv).

10 Kar \& Radin, supra note I, at I I 48.

11 On the ambiguity of meaning, see C.K. OGDEN \& I.A. Richards, THE MEANing OF MEANING I86-87 (8th ed. 1946) (exploring different senses of "meaning"); Michael L. Geis, On Meaning: The Meaning of Meaning in the Law, 73 WASH. U. L.Q. I I 25, I I $25^{-2} 6$ (I995) (observing that the Supreme Court uses the words "mean" and "meaning" in multiple ways); A.P. Martinich, Four Senses of "Meaning" in the History of Ideas: Quentin Skinner's Theory of Historical Interpretation, 3 J. PHIL. HIST. 225, 226 (2009) ("Equivocating on the word 'meaning' is easy both because that word has several related senses and because understanding the meaning of a text in one of these senses is crucial to understanding its meaning in another sense."); Lawrence B. Solum, Intellectual History as Constitutional Theory, IOI VA. L. REV. I I I I, I I I5-I6 (20I5).
} 
content produced by an utterance or writing in context. This observation brings us to our next topic, the distinction between semantics and pragmatics.

2. Semantics and Pragmatics. - What are the mechanisms of communication? How do speakers and authors successfully convey their communicative intentions to listeners and readers? One way to answer these questions begins with the distinction between "semantics" and "pragmatics." For readers unfamiliar with the philosophy of language and theoretical linguistics, a word of caution: the word "pragmatics" in the context of the semantics-pragmatics distinction has very little connection to the words "pragmatic" and "pragmatism" as they are used in legal theory.

The distinction between semantics and pragmatics is contested in the philosophy of language and theoretical linguistics, but for our purposes, the following discussion by Bach will suffice to provide a working vocabulary: "[S]emantic information pertains to linguistic expressions . . . whereas pragmatic information pertains to utterances and facts surrounding them. Semantic information about sentences is part of sentence grammar, and it includes information about expressions whose meanings are relevant to use rather than to truth conditions." 12

Bach continues:

Pragmatic information concerns facts relevant to making sense of a speaker's utterance of a sentence (or other expression). The hearer thereby seeks to identify the speaker's intention in making the utterance. In effect the hearer seeks to explain the fact that the speaker said what he said, in the way he said it. Because the intention is communicative, the hearer's task of identifying it is driven partly by the assumption that the speaker intends him to do this. The speaker succeeds in communicating if the hearer identifies his intention in this way, for communicative intentions are intentions whose "fulfillment consists in their recognition." Pragmatics is concerned with whatever information is relevant, over and above the linguistic properties of a sentence, to understanding its utterance. ${ }^{13}$

Returning to Grice's distinction between "speaker's meaning" and "sentence meaning," we can now say that the sentence meaning of an utterance or text is its "semantic meaning," whereas the speaker's meaning of an utterance includes the pragmatic dimension of meaning. Semantic meaning is acontextual; pragmatics takes context into account.

(a) The Mechanisms of Semantics: Conventional Semantic Meanings and Syntax. - How is literal meaning conveyed? What produces the semantic content of an utterance or writing? A basic answer to these questions begins with the idea that words and phrases have conventional semantic meanings, produced by patterns of usage. Words and

12 Kent Bach, The Semantics-Pragmatics Distinction: What It Is and Why It Matters, S.F. ST. U., http://userwww.sfsu.edu/kbach/spd.htm [https://perma.cc/E8NZ-5VFC].

13 Id. (citation omitted). 
phrases are combined into large units, sentences, by syntax, roughly the regularities of grammar and punctuation that we sometimes call "rules."

The line between semantics and pragmatics can be drawn in various ways. One question concerns the role of contextual disambiguation. A sentence like "The bank is closed." might refer to a financial institution or a public park adjoining a river. For our purposes, it doesn't matter whether the semantic content of such a sentence is considered ambiguous or if we use the phrase "semantic content" to refer to the contextually disambiguated meaning. Whether we put contextual disambiguation on the semantic or the pragmatic side of the ledger, the full communicative content includes pragmatics - and it is the full communicative content that is important for the purposes of interpreting legal texts.

There are many different types of communicative situations involving linguistic exchanges: ordinary conversations about the weather, oral exchanges involving offers and acceptances, drafting statutes, drafting contracts, and so forth. When we use language to communicate, we take advantage of the conventional semantic meanings of words and phrases and the conventions of grammar and punctuations. In other words, we can use literal meaning to communicate. But literal meaning is not the only tool. In ordinary communication, we are not in the situation of someone who puts a message in a bottle, where the only context available to an unknown future reader is the fact that the words were found written on a scrap of paper and placed by someone in a bottle that was tossed in the sea. Ordinary communication almost always involves a context that can enrich the meaning of what we say or write. This is the domain of pragmatics.

(b) The Mechanisms of Pragmatics. - How do we take advantage of context to communicate content that is richer than literal meaning? We have already discussed contextual disambiguation. If I write a contract using the word "bank," it is quite likely that I dispense with explicit disambiguation and rely on context to convey which sense of "bank" is intended. But context can operate in other ways to enrich the communicative content of a text or utterance. The phrase "pragmatic enrichment" is used to refer to this phenomenon, although we might use "contextual enrichment" to avoid the associations that "pragmatic" has for lawyers and legal theorists. ${ }^{14}$

Here are four illustrative forms of contextual enrichment, briefly described and illustrated by example ${ }^{15}$ :

Implicature: The word "implicature" was coined by Grice to name the way in which an utterance can convey communicative content that is different from its semantic content. ${ }^{16}$ The classic example is a letter

\footnotetext{
14 See Lawrence B. Solum, Originalist Methodology, 84 U. CHI. L. REV. 269, 288 (20I 7).

15 See id. at 288-9.

16 See Wayne Davis, Implicature, Stan. Encyclopedia PhIL. (Sept. 6, 20I9), http://plato.stanford.edu/entries/implicature [https://perma.cc/4D6S-M $27 \mathrm{Y}$ ].
} 
of recommendation. Suppose that I write a letter for a student applying for a Supreme Court clerkship. The letter reads as follows: "I recommend Alice. They were always on time to class and their attendance record was perfect." Literally, the letter communicates a recommendation supported by information about punctuality and attendance. But in the context, this letter is actually a warning and not a recommendation at all. If the best that can be said about Alice is that they were on time and did not miss class, the implicature is that Alice is not suitable for the position of judicial clerk.

Impliciture: Impliciture involves situations in which what is said implicitly includes something else that is closely related. ${ }^{17}$ For example, if I say "Jack and Jill are married," this frequently communicates some additional information, which could have been stated explicitly as follows: "Jack and Jill are married [to each other]." Article I, Section 9 of the Constitution explicitly states, "No Bill of Attainder or ex post facto Law shall be passed," with [by Congress] as an impliciture. ${ }^{18}$

Presupposition: Presupposition involves an unstated assumption that is conveyed by what is said. ${ }^{19}$ If I say, "Cass is no longer the head of OIRA," I also communicate that Cass was once the head of OIRA. Likewise, if I say, "Adrian is now a Catholic," I communicate that Adrian at one time was not a Catholic. ${ }^{20}$ The constitutional text may have a variety of presuppositions. Famously, the Ninth Amendment may presuppose the existence of "other" rights "retained by the People," even though it does not say this explicitly. ${ }^{21}$

Modulation: The intuitive idea is that a conventional semantic meaning can be adjusted or modulated to fit the context - essentially a new meaning is created (sometimes on the spot) so that an old word is used in a new way. ${ }^{22}$ In the law, modulation can create a new technical

17 Kent Bach, Conversational Impliciture, 9 MIND \& LANGUAGE I24, I 26 (I994).

18 U.S. CONST. art. I, § 9, cl. 3.

19 See, e.g., Philippe Schlenker, Be Articulate: A Pragmatic Theory of Presupposition Projection, 34 TheORETICAL Linguistics I57, I6 I (2008); Bas C. van Fraassen, Presupposition, Implication, and Self-Reference, 65 J. PHIL. I36, I37-39 (I968); David I. Beaver \& Bart Geurts, Presupposition, StAN. ENCYClOPEDIA PHIL. (Apr. I, 20II), https://plato.stanford.edu/entries/ presupposition [https://perma.cc/YX 3 F-QFXX].

20 Philosophers of language distinguish between "conversational presuppositions" (also called "speaker presuppositions" or "pragmatic presuppositions") and "conventional presuppositions" (or "semantic presuppositions") that are triggered by particular words or phrases ("no longer" in the first example above). See Beaver \& Geurts, supra note i9. For our purposes, we can put these technicalities to the side.

21 See U.S. CONST. amend. IX; Lawrence B. Solum, Originalism and the Unwritten Constitution, 2013 U. ILL. L. REV. I935, I958-6I.

22 François Recanati explains modulation as follows:

Sense modulation is essential to speech, because we use a (more or less) fixed stock of lexemes to talk about an indefinite variety of things, situations and experiences. Through 
meaning for a word that also has an ordinary sense. For example, the Recess Appointments Clause uses the word "recess," the literal meaning of which could refer to any break in the business of the Senate. ${ }^{23}$ In context, "recess" may be limited to the break between sessions of the Senate. ${ }^{24}$ If so, then the constitutional meaning of "recess" in the clause is a modulation of the conventional semantic meaning of the word.

Finally, there is a residual category of "free enrichments" that do not fit into any of these categories. ${ }^{25}$ For present purposes, the category of free enrichment and any other forms of pragmatic enrichment are set aside.

Some legal texts aim to be more explicit than do face-to-face oral conversations: contracts between sophisticated business entities that govern complex construction projects may be an example. Some legally operative utterances are face-to-face oral conversations; the dance of offer and acceptance in a simple contract between a homeowner and a handyman could illustrate this situation. But whether a legal communication is oral or written, meaning is a product of both semantics and pragmatics. Literal meaning, contextual disambiguation, and pragmatic enrichment all play a role in conveying communicative intentions and hence in the creation of shared meaning.

3. The Role of the Gricean Maxims and Alternatives Thereto. Grice's maxims of conversation play a central role in Kar and Radin's account of shared meaning. The maxims are rules of thumb that enable readers and listeners to grasp the author or speaker's communicative intentions. Here is the list of maxims, formulated concisely:

The maxim of quantity, provide as much information as needed but no more. ${ }^{26}$

The maxim of quality, be sincere. ${ }^{27}$

The maxim of relation, be relevant. ${ }^{28}$

The maxim of manner, be clear and avoid obscurity. ${ }^{29}$

the interaction between the context-independent meanings of our words and the particu-

lars of the situation talked about, contextualized, modulated senses emerge, appropriate to the situation at hand.

FRANÇOIS RECANATI, LITERAL MEANING I3I (2004) (footnote omitted).

23 See Noah Webster, American Dictionary of the English Language (i 828 ), http://webstersdictionary 1828.com/Dictionary/recess [https://perma.cc/3EZ4-M6N3] (defining "recess" as "[r]emission or suspension of business or procedure; as, the house of representatives had a recess of half an hour").

24 See NLRB v. Noel Canning, 573 U.S. 5 I3, 575 (20I4) (Scalia, J., concurring in the judgment) ("A sensible interpretation of the Recess Appointments Clause should start by recognizing that the Clause uses the term 'Recess' in contradistinction to the term 'Session.'”).

25 Nicholas Allott, Key Terms in Pragmatics 80 (2010).

26 GRICE, supra note 2, at 26.

27 Id. at 27 .

28 Id.

29 Id. 
Grice's maxims are not like the rules of chess. In chess a move contrary to the rules does not count or results in a penalty such as forfeiture, but in conversation, a certain amount of redundancy, insincerity, irrelevance, and obscurity is par for the course. Grice's maxims are rules of thumb - generalizations that help us grasp communicative intentions most of the time, in most communicative situations, for most speakers.

Perhaps it is unwise to use President Trump as an example, but it seems likely that the President frequently communicates in ways that do not conform to the Gricean maxims, adding extraneous comments that are duplicative, including statements not supported by evidence, straying from the topic, and speaking in ways that are disorderly, obscure, and ambiguous. Nonetheless, President Trump does communicate. Violating the maxims of conversation might lead to misinterpretation, but ordinarily, an expression that includes redundancy, insincerity, or irrelevancy will be comprehensible. Obscurity is different; if an expression is sufficiently obscure or unclear, it may be incomprehensible.

In many cases, it is obvious that slavish adherence to the maxims would result in misunderstanding. If the maxims were to be understood as binding rules, the outcome would frequently be misinterpretation. The immediately prior two sentences are substantially redundant, violating the maxim of quantity: if one tried to assign them conceptually distinct meanings, the result would be misinterpretation.

Contracts are frequently drafted in a way that includes deliberate redundancy - sometimes to avoid misunderstanding, ${ }^{30}$ but other times as a result of somewhat mindless combination and copying of prior contracts dealing with the same type of transaction. ${ }^{31}$ This is not to say that the maxim of quantity does not have a legal analogue: the antiredundancy canon is cited in contract cases and elsewhere. ${ }^{32}$ But in the law as in human communication generally, redundancy may serve important functions. ${ }^{33}$ And redundancy may exist even when it serves no function at all, but is simply the result of an oversight or error.

30 See John M. Golden, Redundancy: When Law Repeats Itself, 94 TEx. L. REV. 629, 63I-32, 645 (2016) ("[Generally,] attention to the actual results of legal drafting and the motivations of legal drafters suggests that drafters of legal documents ranging from statutes to contracts pay no more than limited heed, if any, to concerns with avoiding redundancy." Id. at 63I-32.).

31 See Lori D. Johnson, Say the Magic Word: A Rhetorical Analysis of Contract Drafting Choices, 65 SYRACUSE L. REV. 45 I, 46I-62 (20I5) (observing that contract drafters may uncritically repeat language from old contracts because they are unsure of its meaning).

32 See Golden, supra note 30, at 655-56.

33 See Henry E. Smith, The Language of Property: Form, Context, and Audience, 55 STAN. L. REV. II05, II57, II6I (2003) ("Redundancy in legal communication is valued because of the large number of potentially interfering messages being sent. To this one can add that a more heterogeneous audience is likely to find redundancy helpful in processing a message." Id. at I I 57 (footnote omitted).). 
The maxims are formulated for the purpose of describing cooperative communication, but in legal contexts, including contractual communication, this assumption does not always hold. We need to differentiate between strategic and cooperative legal communication - a topic that is explored below. ${ }^{34}$ Moreover, the maxims are controversial in the philosophy of language and theoretical linguistics. For example, what is called "relevance theory" replaces the maxims with a generalized principle of efficiency. ${ }^{35}$

Grice's maxims point to important features of communications, but the meaning of an utterance or text is not determined by the maxims. Communicative intentions can be successfully communicated without adherence to the maxims, and some communication occurs in contexts in which the assumption that communication is cooperative does not hold. Understanding a speaker or author requires that we grasp their communicative intention and the maxims are means to that end - tools or rules of thumbs that do not play a constitutive role in communication.

4. Speech Act Theory. - In How to Do Things with Words, ${ }^{36}$ the philosopher J.L. Austin developed the notion of a "speech act." 37 Professor Mitchell Green provides the following definition: "[S]peech acts are those acts that can (though need not) be performed by saying that one is doing so."38 There are many things that one can do with words, including promising, apologizing, ordering, threatening, and countless others. ${ }^{39}$ Some speech acts involve the law. By saying something or writing something, a speaker can do something with legal effect. Examples of "legal speech acts" ${ }^{40}$ include placing someone under

34 See infra section I.B.3(c), pp. 43-45.

35 See Davis, supra note i6 ("Neo-Gricean theories modify Grice's principles to some extent, and Relevance theories replace them with a principle of communicative efficiency."); see also Deirdre Wilson \& Dan Sperber, Relevance Theory, in HANDBOOK OF PRAGMATICS 607 (Laurence R. Horn \& Gregory Ward eds., 2004).

36 J.L. Austin, How to Do Things with Words (J.O. Urmson \& Marina Sbisà eds., 2d ed. i975) [hereinafter Austin, How to Do ThINGS WITH WORDS].

37 See generally id.; J.L. Austin, Philosophical PAPERS (J.O. Urmson \& G.J. Warnock eds., 3d ed. I979); G.J. WARNOCK, J.L. AUSTIN (1989). Many other theorists have contributed to speech act theory. See generally New WORK ON SpeECh ACTS (Daniel Fogal, Daniel W. Harris \& Matt Moss eds., 20i8); John R. Searle, Speech Acts: An Essay in the Philosophy of Language (i 969); Speech ACt Theory and Pragmatics (John R. Searle, Ferenc Kiefer \& Manfred Bierwisch eds., I980); John R. Searle, How Performatives Work, I2 Linguistics \& PHIL. 535 (I989).

38 Mitchell Green, Speech Acts: Content, Force, and How Saying Can Make It So, STAN. ENCYCLOPEDIA PHIL. (Oct. 2, 20I4), https://plato.stanford.edu/entries/speech-acts/\#ConForHowSayMakItSo [https://perma.cc/4NTF-ECSH].

39 See id.

40 See generally, e.g., Marianne Constable, Our Word Is Our Bond: How Legal SPEECH ACTS (20I4); DENNIS KuRZON, IT Is HEREBY PERFORMED . . . : EXPLORATIONS IN Legal Speech ACTS (I986); Paul Amselek, Philosophy of Law and the Theory of Speech Acts, I RATIO JURIS I87 (I988). 
arrest, marrying persons to each other, testifying in court, and promulgating an executive order. ${ }^{41}$ Contracting involves a variety of speech acts, importantly including offering and accepting - and in the case of written contracts, affixing a signature to a written agreement. ${ }^{42}$

Austin developed a technical vocabulary for analyzing speech acts, distinguishing between "locution," "illocution," and "perlocution" as follows:

Locutionary act: the uttering of a meaningful sentence. ${ }^{43}$ Example: Ben says, "I will fix the wall." The locutionary act is Ben's utterance of the sentence.

Illocutionary force: the speech act that is performed via the utterance. $^{44}$ Example: Ben says, "I will fix the wall" and thereby promises to fix the wall. The illocutionary force is promising - a type of speech act.

Perlocutionary effect: the effect produced by the speech act. Example: Ben says, "I will fix the wall," thereby promising to do so, and this promise has the effect of inducing Alice to rely on Ben's promise. ${ }^{45}$ The perlocutionary effect is the reliance by Alice induced by the promise. ${ }^{46}$

In the discussion that follows, I will emphasize the idea that the content of an utterance can be distinguished from its force. The content of a locution is its "meaning," very roughly the disambiguated semantic content of the utterance. ${ }^{47}$ The illocutionary force of a speech act is distinct from its content. The force of an utterance that makes a promise is promising. The force of an utterance that pronounces two persons to be married is marrying. The force of an utterance that places someone under arrest is arresting. 48

This next bit is very important. If you are not already familiar with speech act theory, I urge you to pay close attention. Perhaps you should read this paragraph twice. The very same utterance (the same string of

41 Daniel W. Harris, Daniel Fogal \& Matt Moss, Speech Acts: The Contemporary Theoretical Landscape, in NEW WORK ON SPEECH ACTS, supra note 37, at I, I.

42 Sanford Schane, Contract Formation as a Speech Act, in The Oxford Handbook of LANGUAGE AND LAW I00, I05-08 (Peter M. Tiersma \& Lawrence M. Solan eds., 2012); Peter Meijes Tiersma, The Language of Offer and Acceptance: Speech Acts and the Question of Intent, 74 CALIF. L. REV. I89, I89, 206 (I986).

43 Austin, How to Do Things With Words, supra note 36, at 94.

44 See id. at 98-100.

45 See id. at Ior.

46 See id. The following formulation is useful: "In singling out illocutionary acts for theoretical attention, Austin distinguished them from locutionary acts, which are mere utterances of meaningful expressions, and perlocutionary acts, which are acts of producing effects that are causally downstream from illocutionary acts." Harris, Fogal \& Moss, supra note 4I, at I.

47 The full content of an utterance in context may include pragmatic enrichments, content that is added by the context in which the utterance occurs. See Solum, supra note I4, at 273.

48 See Harris, Fogal \& Moss, supra note 4I, at 22. 
words) can have different illocutionary forces in different contexts. Thus, "I will fix the wall" can be a prediction or a promise, depending on the context of utterance ${ }^{49}$ :

Example I: Alice, "What do you think you will do tomorrow?" Ben, "I will fix the wall."

Example 2: Alice, "Do you promise to fix the wall?" Ben, "I will fix the wall."

In Example I, the utterance "I will fix the wall" expresses Ben's belief that fixing the wall will be his primary activity on the next day: the force of the utterance is assertion. In Example 2, the utterance "I will fix the wall" is the making of a promise. ${ }^{50}$ The semantic content is the same in Examples I and 2, but the illocutionary force is different. Competent speakers of a natural language understand this distinction intuitively as a result of pragmatic enrichment. ${ }^{51}$ We are able to recognize the difference in force between Example I and Example 2, although it might be a bit tricky trying to explain the difference precisely in ordinary English. Speech act theory aims to describe and explain the way communication works in a theoretical vocabulary that allows us to draw this distinction in a relatively precise way. ${ }^{52}$

\section{B. Step Two: Legal Communication}

So far, we have been investigating linguistically mediated communication in general. We now turn our attention to legal communication. We can begin with a typology - a preliminary and incomplete listing of some of the types of legal speech acts.

I. An Incomplete Typology: Legal Speech Acts. - Legal communications can be divided into types that have distinctive illocutionary forces. When an officiant pronounces a couple as husband and husband, wife and wife, or wife and husband, they perform a distinctive speech act - marrying. When a legislative staffer drafts a statute for consideration by a committee, they perform a distinctive speech act proposing language for committee consideration. ${ }^{53}$ When parties negotiate a contract, they may perform the distinctive speech acts of offering and accepting. Here is a tentative and incomplete list of the types of legal speech acts:

\footnotetext{
49 Prediction and promise are not the only possibilities. "I will fix the wall" could also be used to convey a statement of intention or plan. I am indebted to Professor Brian Bix for this point.

50 If you resist this conclusion, you might imagine a richer context that makes the promise crystal clear.

51 In Example 2, Ben's statement includes an impliciture: [Yes, I promise that] I will fix the wall. The implicit content is recognizable because of Alice's preceding question.

52 Kar and Radin offer a similar example. See Kar \& Radin, supra note I, at I I 57-58.

53 The word "propose" may have a technical sense, in which only members of the legislature can officially "propose" a statute for consideration by a committee. In this example, the staffer would not propose the statute in this technical sense. I am grateful to Bix for this point.
} 
Contractual speech acts: offering, accepting, rejecting, drafting, declaring an intention to breach, and rescinding.

Constitutional speech acts: drafting, proposing for consideration by a constitutional convention, voting for a proposal at a convention and thereby proposing for ratification, voting against a proposal, and voting to ratify. Similar speech acts are involved in the amendment process.

Statutory speech acts: drafting, proposing to a committee, voting out of committee, voting against in committee, voting for on the floor of a legislative body, voting against on the floor, signing into law, speaking in favor of a proposal, speaking against a proposal.

Judicial speech acts: voting for or against an outcome in conference, proposing a draft majority opinion, joining a draft opinion, proposing a draft dissenting opinion, joining a dissent, and overruling a prior decision.

2. The Situations of Legal Communication. - There are many types of legal communication and some of these types involve characteristic situations of legal communication. The situations provide context that enables contextual disambiguation and pragmatic enrichments. Consider the distinct communicative situations involved in constitutional, statutory, and judicial communication.

(a) The Situation of Constitutional Communication. - The nature of constitutional communication could be disputed, but I believe that the best account conceives of constitutional communication as involving a complex multistage process in which public meaning plays a crucial role. The actual sequence of events is too complex to recount here, but we can imagine a simplified version of the events that resulted in the ratified text that was implemented by the First Congress in $\mathrm{I} 79 \mathrm{I}^{54}$ :

Stage One: Various proposals (such as the Virginia Plan and the New Jersey Plan) are circulated and discussed at the Philadelphia Convention.

Stage Two: Various resolutions are introduced, debated, amended, and adopted by the Convention.

Stage Three: The Committee of Detail refines these resolutions and proposes a coherent plan for the final drafting of the constitutional text as a whole, and this plan is debated on the floor of the Convention.

Stage Four: The amended plan adopted on the floor is referred to the Committee of Style. Gouverneur Morris (perhaps with the help of

54 There are many accounts of the Constitutional Convention, including RICHARD BEEMAN, Plain, Honest Men: THE MAKING OF THE AMERICAN CONSTITUTiON (2009); EDWARD J. Larson \& Michael P. Winship, The Constitutional Convention: A Narrative History From the NOTES OF JAMES MADISON (2005); THE RECORDS OF THE FEDERAL Convention of i 787 (Max Farrand ed., rev. ed. 1937) (four volumes); John R. Vile, The Constitutional CONVENTION OF i787: A Comprehensive ENCYClopedia OF AMERICA's Founding (rev. 2d ed. 20i6) (two volumes). On ratification, see PaUline Maier, Ratification: The People Debate the Constitution, i $787-\mathrm{I} 788$ (2010). 
James Wilson and others) drafts a proposed constitutional text, which is then voted out of committee, debated, amended, and then adopted by the Convention as a whole.

Stage Five: The constitutional text is transmitted to the Continental Congress and made public. The text is then sent to state legislatures which in turn transmit the text to state ratifying conventions, a sufficient number of which approve the text. During Stage Five, the constitutional text is debated in public and in the ratifying conventions.

Stage Six: The constitutional text is then put into action by the First Congress, which passes legislation governing the election of the first President, enacts legislation creating the structure of the new government, and begins to exercise various powers granted to it by the new Constitution.

How does this complex multistage process create "shared constitutional meaning"? Again, the full story is beyond the scope of this Response, but a rough sketch is possible.

Although fragments of the constitutional text actually emerged at earlier stages, in the simplified model, the constitutional text is drafted at Stage Five. When Gouverneur Morris drafts the text, he hopes to convey his communicative intentions to multiple audiences. His immediate audience likely included others who participated in the drafting process, followed by the other members of the Committee of Style. Morris aims to convey his communicative intentions to the other members of the Committee, and they aim to recover his communicative intentions. When the delegates on the convention floor receive the draft from the Committee of Style, they aim to recover the communicative intentions of the drafters as understood by the members of the Committee. And when the final constitutional text is passed to the public, the Continental Congress, state legislatures, and eventually to implementing officials, all of these readers aim to recover the communicative intentions of the drafters - even though it seems likely that they would not have known who the actual drafters were.

In the case of constitutional communication, the drafters aimed to produce a text with meaning that would be accessible to the public: this claim is central to Public Meaning Originalism and can be called the "Public Meaning Thesis." 55 Justice Story stated the idea:

In the first place, then, every word employed in the constitution is to be expounded in its plain, obvious, and common sense, unless the context furnishes some ground to control, qualify, or enlarge it. Constitutions are not designed for metaphysical or logical subtleties, for niceties of expression, for critical propriety, for elaborate shades of meaning, or for the exercise of philosophical acuteness, or judicial research. They are instruments of a

55 See Lawrence B. Solum, The Public Meaning Thesis: An Originalist Account of Constitutional Interpretation 8 (Apr. 9, 20I8) (unpublished manuscript) (on file with the Harvard Law School Library and most recent version available from the author). 
practical nature, founded on the common business of human life, adapted to common wants, designed for common use, and fitted for common understandings. The people make them; the people adopt them; the people must be supposed to read them, with the help of common sense; and cannot be presumed to admit in them any recondite meaning, or any extraordinary gloss. ${ }^{56}$

If the Public Meaning Thesis is correct, ${ }^{57}$ then the drafters of the constitutional text aimed to convey their communicative intentions to the public. Subsequent readers, including the members of the Committee of Style, the delegates to the Philadelphia Convention, the public, and implementing officials and judges (including Justice Story) would have understood that the relevant meaning of the text was its public meaning. Because the Philadelphia Convention deliberated in secret, the context of constitutional communication does not include "legislative history," but it does include public discussion and debate, including the Federalist and Antifederalist Papers.

(b) The Situation of Statutory Communication. - Another example of legal communication is provided by the legislative process. Here is a simplified model of statutory communication ${ }^{58}$ :

Stage One: A committee staffer drafts a proposed statute and passes the draft to a legislator, who introduces the draft as a proposed bill.

Stage Two: The draft is referred to committee, where it may be discussed and amended.

Stage Three: The committee votes to send the amended draft bill to the floor of the legislature, where it may be discussed and amended.

Stage Four: The legislature votes to approve the bill and sends it to the executive for signature or veto.

Stage Five: The executive signs the bill and it is published as a law.

Of course, actual legislative processes are more complex and may involve bicameral legislatures, multiple committees, and multiparty negotiations among interested stakeholders who are not formally part of the legislature. The actual drafter of legislative text might be a legislator, staffer, employee of an industry association or public interest group,

56 I JOSEPH STORY, COMmentaries ON THE CONSTITUtion OF THE UNITEd STATES 436-37 (Boston, Hilliard, Gray \& Co. I833); see also National Prohibition Cases, 253 U.S. 350, 398 ( 1920 ) ("[I]n the exposition of statutes and constitutions, every word 'is to be expounded in its plain, obvious, and common sense, unless the context furnishes some ground to control, qualify, or enlarge it,' and there cannot be imposed upon the words 'any recondite meaning or any extraordinary gloss.'” (McKenna, J., dissenting) (quoting STORY, supra, at 436-37)).

57 The case for the Public Meaning Thesis is made in Solum, supra note 55.

58 For descriptions of the actual process, see Walter J. Oleszek, MARK J. Oleszek, Elizabeth Rybicki \& BILl Heniff JR., CONGRESSIONAl Procedures AND THE POLICY Process (Ioth ed. 20I6); BARbara Sinclair, UNORTHOdOX LAWMAKING: NeW LEGiSLATIVE PROCESSES IN THE U.S. CONGRESS (5th ed. 20I 7 ). 
or someone else. ${ }^{59}$ When the text of a statute passes from drafter to member to committee to the floor, those with formal voting power may or may not read the text. ${ }^{60}$ A legislator who votes for a statute might ask a staffer to read and summarize the statutory text or might instead rely on advice from the leadership of their party. ${ }^{61}$

The intended readership of a statute might be the public, but this is not necessarily the case. Some statutes might be primarily aimed at a regulatory agency and the industry that it regulates. If the drafter of a statute intends to communicate to a narrow group that employs technical language (terms of art), then the drafter may assume that the readers of the statute will understand the words and phrases in their technical and not ordinary senses. In other words, there are many different situations of legislative communication. Grasping the communicative content of a statutory text may require a particular reader to know who the drafter had in mind as the intended readers of the text: if a judge is reading a text that was written for a regulatory agency, the judge may need to acquire knowledge of technical terms to grasp the communicative intentions of the drafter.

(c) The Situation of Judicial Communication. - Judicial communication has its own complex structure. Again, we can lay out a simplified model of communication by an appellate court:

Stage One: After oral argument, the judges confer and make a tentative opinion. The senior judge assigns the opinion to a member of the panel or court.

Stage Two: The law clerks for the judge draft a sample opinion, which is then edited by the judge and rewritten by the clerks. This process may be repeated several times.

Stage Three: The judge approves a draft opinion and circulates it to the other members of the panel or court. Other judges may offer comments, resulting in modifications to the opinion.

Stage Four: A majority of judges join the opinion, which is then published.

Of course, the actual processes are more varied. Some judges write their own opinions. Portions of an opinion may be written by someone other than the author judge (for instance, another judge or a law clerk for another judge). Passages may be borrowed from other opinions, the briefs, or academic writing. Some judges may not read draft opinions written by their clerks or may delegate the reading of circulated opinions to their clerks.

Some judicial opinions may be self-consciously written in part for the public: opinions of the United States Supreme Court in high profile

\footnotetext{
59 See, e.g., Victoria F. Nourse \& Jane S. Schacter, The Politics of Legislative Drafting: A Congressional Case Study, 77 N.Y.U. L. REV. 575, 585-88 (2002).

60 See, e.g., id. at 608 .

61 See, e.g., Jesse M. Cross, The Staffer's Error Doctrine, 56 HARV. J. ON LEGIS. 83, 98-99 (20I9).
} 
cases might contain passages that are intended to communicate directly to the general public. But in most cases, it seems likely that judicial opinions are written for lawyers and judges. Appellate opinions address the parties to the particular dispute, the lower court judges to whom the case is remanded, and future courts that may be bound by the horizontal or vertical stare decisis effects of the opinion. Most judicial opinions are written for lawyers and judges using words in their technical legal senses and with an awareness of the special conventions that govern judicial opinions. First-year law students become acutely aware of the gap between ordinary meaning and specialized legal meanings when they first begin to read judicial opinions - some of which may be quite difficult to comprehend.

(d) The Importance of Multiple Intended Readers in Complex Multistage Legal Communication. - In each of the situations described above, legal communication includes multiple stages and multiple intended readers. Thus, the drafter of a constitutional provision at the Philadelphia Convention intended to communicate to the public, but also to committee members, other members of the Convention, the Continental Congress, the ratifying conventions, officials who will implement the Constitution, and judges who will resolve disputes arising under the Constitution. The drafter of a statute may intend to communicate to legislators, staffers, lawyers, judges, and regulators, in the case of a regulatory statute - or to the public rather than regulators in the case of a general criminal law that applies to the public at large. The drafter of a judicial opinion intends to communicate to judges and lawyers as the primary intended readership, although some opinions may include passages intended to be read by the public.

Multiple readerships create the possibility that a drafter's communicative intentions will be understood differently by different categories of readers. Such divergence may be unintentional. The drafter of a statute may not have anticipated the regulators and courts would have different understandings of the same statutory language. ${ }^{62}$ But it is also the case that a drafter might deliberately attempt to communicate different content to different readerships. A constitutional clause might be drafted to be susceptible of an innocuous interpretation during the ratification process but a more radical interpretation by implementing officials and by courts. ${ }^{63}$

62 This leads to the set of issues addressed by the Chevron doctrine. See Lawrence B. Solum \& Cass R. Sunstein, Chevron as Construction, I05 CORNELL L. REV. (forthcoming 2020), https://ssrn.com/abstract=3300626 [https://perma.cc/59F 3-KK6D].

63 This possibility is raised by Professor John Mikhail's discussion of the Necessary and Proper Clauses and their relationship to the Preamble. See John Mikhail, The Necessary and Proper Clauses, I02 GEO. L.J. I045, I070 (2014) ("Wilson and the other principal framers of the Constitution knew exactly what they wanted to accomplish by adding a complex and ambiguous sweeping 
Similarly, written contracts may have multiple intended readerships. A contract might be drafted with an intended readership that encompasses both the contracting parties and judges in the event of a dispute that results in litigation. Divergent meanings might arise inadvertently, but it is also possible that a drafter might deliberately communicate one message to a contractual partner and a different message to a judge. This possibility is discussed below in connection with the distinction between strategic and cooperative communication. ${ }^{64}$

3. The Conceptual Structure of Legal Communication. - Three foundational distinctions are prerequisites to any understanding of legal communication. The first distinction is that between communicative content and legal content. The second distinction marks the difference between "interpretation" (the discovery of the communicative content of a legal speech act) and "construction" (the determination of the legal effect given to that content). The third distinction is between "cooperative" and "strategic" communication. Each distinction is considered in turn.

(a) First Distinction: Communicative Content and Legal Content. The first foundation distinction is between communicative content and legal content. ${ }^{65}$ One way to approach this distinction begins with the idea of "content" itself and then proceeds to unpack the difference between the communicative content of a legal text and the legal content associated with that text.

When I use the word "content" and the phrase "communicative content" I do not mean to refer to words, phrases, and sentences. I am using "content" to refer to abstract entities such as concepts and propositions. Words are used to represent concepts. The word "law" in English represents the same concept as the word "ley" in Spanish. And the concept of law can be expressed in English using other words, such as "system of legal norms." As words are to concepts, so sentences are to propositions. When I write a sentence in English, I express a proposition that could be translated into another language or paraphrased using a different English sentence.

The communicative content of a legal text is conceptually distinct from the legal content. For example, the Constitution of the Confederacy has communicative content, but that legal text does not produce legal content. No propositions of law follow from the Confederate constitution. Likewise, a draft written contract can have

clause to the end of the list of enumerated powers in the Constitution. Indeed, the best reading of the evidence suggests that they probably saw this ambiguity as a virtue rather than a vice.").

64 See infra section I.B.3(c), pp. 43-45.

65 See generally Lawrence B. Solum, Communicative Content and Legal Content, 89 NotRE DAME L. REV. 480 (2013). 
communicative content, but if it is not signed by the parties, it produces no legal content.

Similarly, the legal content associated with a text can be different from its communicative content. For example, 66 the First Amendment begins "Congress shall pass no law," 67 but the Supreme Court has applied the freedom of expression to the judicial branch in cases like New York Times v. Sullivan. ${ }^{68}$ The legal content associated with a contract can vary from its communicative content for a variety of reasons. Contract law includes "default rules" that provide legal content that is not included in the contract itself. ${ }^{69}$ Similarly, the "mandatory rules" of contract law forbid certain kinds of agreements, for example, those that are contrary to public policy. ${ }^{70}$

Communicative content and legal content are conceptually distinct: cases of divergence are important, because they make the distinction visible. But in many legal contexts, the communicative content of a legal text is an important determinant of the legal content produced by the text. Indeed, many of the great disputes in legal theory are about the proper relationship between communicative content and legal content. Consider the following familiar examples:

Public Meaning Originalism affirms the Constraint Principle: the original public meaning of the constitutional text should constrain the legal content of constitutional doctrine. ${ }^{71}$ Many versions of living constitutionalism reject the Constraint Principle and affirm a power for constitutional actors, including judges, to adopt constitutional constructions that are inconsistent with communicative content of the text. ${ }^{72}$

Plain Meaning Textualism affirms that the plain meaning (communicative content) of a statutory text should constrain the legal content of statutory constructions. Purposivism affirms that the legal content of statutory constructions should be determined by the objective purpose or function of the statutory text, even if the resulting constructions are inconsistent with the communicative content of the text.

\footnotetext{
66 For a further discussion of this example, please see $i d$. at 5 I 2 .

67 U.S. CONST. amend. I.

68376 U.S. 254 (1964) (extending First Amendment protections of the freedom of the press to a state-created defamation law).

69 For a further discussion of this example, please see Solum, supra note 65, at 493-94.

70 See Lawrence B. Solum, The Boundaries of Legal Discourse and the Debate over Default Rules in Contract Law, 3 S. CAL. INTERDISC. L.J. 3 I I , 3 I 2 (I993).

71 See generally Lawrence B. Solum, The Constraint Principle: Original Meaning and Constitutional Practice 2-3 (Mar. 24, 2017) (unpublished manuscript), https://ssrn.com/abstract $=29402$ I5 [https://perma.cc/KMY2-568H].

72 See generally Lawrence B. Solum, Originalism Versus Living Constitutionalism: The Conceptual Structure of the Great Debate, I 3 NW. U. L. REV. I243, I2 7 I-77 (2019).
} 
The theoretical debates between originalists and living constitutionalists and between textualists and purposivists provide examples of the importance of the theoretical distinction between communicative content and legal content.

(b) Second Distinction: Interpretation and Construction. - The second distinction is between interpretation and construction. ${ }^{73}$ The distinction has a long history in American legal theory, ${ }^{74}$ including important work done by the great contract treatise writer, Arthur Corbin. ${ }^{75}$ For the purposes of this Response, I will stipulate the following definitions:

Interpretation is the activity that discerns the meaning (communicative content) of an utterance or text.

Construction is the activity that determines the content of constitutional doctrine and the legal effect of an utterance or text.

In the context of contract law, there are two important contexts in which interpretation and construction frequently operate:

Contract Formation: When a court addresses contract formation issues, it may need to determine the communicative content of oral or written exchanges (interpretation); once we know the meaning of the communications between the parties, we then can ask whether particular utterances or writings constitute a legally effective offer and acceptance (construction).

Contract Interpretation and Construction: When a court addresses the issues that arise when a contract is breached, it may need to determine the communicative content of a written or oral contract (interpretation). Once the meaning of a contract's terms has been ascertained, the court may then need to determine their legal effect (construction).

Interpretation and construction operate in contract law and in many other contexts, including constitutional interpretation and construction, statutory interpretation and construction, and so forth.

\footnotetext{
73 See generally Lawrence B. Solum, Originalism and Constitutional Construction, 82 Fordham L. REV. 453 (20I3); Lawrence B. Solum, The Interpretation-Construction Distinction, 27 CONST. COMMENT. 95 (2010).

${ }^{74}$ For the history of the interpretation-construction distinction, see Solum, Originalism and Constitutional Construction, supra note 73, at 487-88. See also Ralf Poscher, The Hermeneutical Character of Legal Construction, in LAW'S HERMENEUTICS: OTHER INVESTIGATIONS 207, 207-08 (Simone Glanert \& Fabien Girard eds., 20I7); Greg Klass, Interpretation and Construction I: Francis Lieber, NEW PRIV. L. (Nov. I9, 2015), http://blogs.harvard.edu/nplblog/2015/1 I/Ig/ interpretation-and-construction-I-francis-lieber-greg-klass [https://perma.cc/5 $\mathrm{EM}_{4}-\mathrm{RPLC}$ ]; Greg Klass, Interpretation and Construction 2: Samuel Williston, NEW PRIV. L. (Nov. 23, 20I5), https://blogs.harvard.edu/nplblog/20I 5/I I/23/interpretation-and-construction-2-samuel-willistongreg-klass [https://perma.cc/HF64-UQJV]; Greg Klass, Interpretation and Construction 3: Arthur Linton Corbin, NEW PRIV. L. (Nov. 25, 20I5), http://blogs.harvard.edu/nplblog/20I5/II/25/ interpretation-and-construction-3-arthur-linton-corbin-greg-klass [https://perma.cc/G 7 RD-PHVS].

75 See Klass, Interpretation and Construction 3: Arthur Linton Corbin, supra note 74.
} 
(c) Third Distinction: Strategic and Cooperative Legal Communication. - The third distinction is between two kinds of legal communication, "strategic" and "cooperative." One way to approach this distinction is via Jürgen Habermas's distinction between "communicative action" and "strategic action." Habermas defined communicative and strategic action as follows:

I count as communicative action those linguistically mediated interactions in which all participants pursue illocutionary aims, and only illocutionary aims, with their mediating acts of communication. On the other hand, I regard as linguistically mediated strategic action those interactions in which at least one of the participants wants with his speech acts to produce perlocutionary effects on his opposite number. ${ }^{76}$

Through communicative action, the participants "pursue illocutionary aims without reservation in order to arrive at an agreement that will provide the basis for a consensual coordination of individually pursued plans of action." 77 The key idea here is the communicative action involves "consensual coordination," an idea that resonates with the foundational notion of consent in contract law and theory.

Adapting Habermas's basic distinction between communicative action and strategic action to legal communication, we can distinguish between cooperative legal communication and strategic legal communication. Let us mark the distinction via two definitions:

Cooperative Legal Communication: Legal communication is cooperative if and only if the drafter or speaker aims to make the same communicative content reasonably available to each and every intended reader or listener without deception.

Strategic Legal Communication: Legal communication is strategic if and only if the drafter or speaker intends to convey different communicative contents to different intended readers or listeners or to convey a message that is deceptive.

These definitions should be viewed as tentative and subject to revision. Complex issues are involved in the precise differentiation of cooperative and strategic legal communication. These definitions provide a "rough and ready" formulation, but further reflection would undoubtedly prompt further revisions and refinements. These definitions are general, in that they apply to various types of legal communication but can be adapted to differentiate between cooperative and strategic contractual communication, constitutional communication, statutory communication, and so forth.

\footnotetext{
76 Jürgen Habermas, The Theory of Communicative ACtion 295 (Thomas McCarthy trans., I 984); see also Lawrence B. Solum, Freedom of Communicative Action: A Theory of the First Amendment Freedom of Speech, 83 Nw. U. L. REV. 54, 9I-93 (I989).

77 HABERMAS, supra note 76 , at 295-96.
} 
The relationship between cooperative versus strategic contractual communication and Kar and Radin's notion of shared versus unshared meaning is complex. Recall that "shared meaning" is communicative content that is grasped by both parties to the agreement. ${ }^{78}$ In the case of an oral contract, the meaning is shared if the communicative content of the offer made by one party is grasped by the party accepting the offer. In the case of a written contract with terms drafted by a third party, shared meaning requires that both parties glean identical communicative content from the text of the agreement.

One way to understand this relationship is via a simple three dimensional two-by-two-by-two matrix. Although the relationship between "shared versus unshared meaning" and "cooperative versus strategic communication" exists in many contexts, both legal and nonlegal, the matrix examines this relationship in the contractual context. The first dimension (horizontal) is "shared meaning" versus "unshared meaning." The second dimension (vertical) is "cooperative contractual communication" versus "strategic contractual communication." The third dimension (represented by two subcells) is "written" versus "oral" contractual agreements. The matrix yields eight examples:

Table I: Sharing and Cooperation in Oral and Written Contracts

\begin{tabular}{|c|c|c|}
\hline $\begin{array}{l}\text { Examples in each cell } \\
\text { assume two contract- } \\
\text { ing parties. }\end{array}$ & Shared Meaning & Unshared Meaning \\
\hline \multirow{2}{*}{$\begin{array}{l}\text { Cooperative } \\
\text { Contractual } \\
\text { Communication }\end{array}$} & $\begin{array}{l}\text { I. Oral Contract: } \\
\text { Oral contract, negoti- } \\
\text { ated in good faith, } \\
\text { terms are mutually } \\
\text { understood. }\end{array}$ & $\begin{array}{l}\text { 5. Oral Contract: } \\
\text { Oral contract, good } \\
\text { faith offer misfires } \\
\text { and the offeror and } \\
\text { offeree have different } \\
\text { understandings. }\end{array}$ \\
\hline & $\begin{array}{l}\text { 2. Written Contract: } \\
\text { Written form con- } \\
\text { tract that is actually } \\
\text { understood by both } \\
\text { parties. }\end{array}$ & $\begin{array}{l}\text { 6. Written Contract: } \\
\text { Terms were not read } \\
\text { by one party but } \\
\text { were reasonably ac- } \\
\text { cessible and antici- } \\
\text { patable. }\end{array}$ \\
\hline $\begin{array}{l}\text { Strategic } \\
\text { Contractual } \\
\text { Communication }\end{array}$ & $\begin{array}{l}\text { 3. Oral Contract: } \\
\text { Oral offer and ac- } \\
\text { ceptance, offeror ac- } \\
\text { cepts knowing that } \\
\text { the legal effect of the } \\
\text { contract will vary }\end{array}$ & $\begin{array}{l}\text { 7. Oral Contract: Of- } \\
\text { feror proposes terms } \\
\text { with different ordi- } \\
\text { nary and legal mean- } \\
\text { ings with intent to } \\
\text { deceive offeree. }\end{array}$ \\
\hline
\end{tabular}

78 See supra section I.A.I, pp. 26-27. 


\begin{tabular}{|l|l|l|}
\hline & $\begin{array}{l}\text { from the communica- } \\
\text { tive content to the of- } \\
\text { feror's advantage. }\end{array}$ & \\
\cline { 1 - 2 } & $\begin{array}{l}\text { Written contract, } \\
\text { Written Contract: } \\
\text { read and understood } \\
\text { by both sides, but one } \\
\text { party intends to } \\
\text { breach and evade lia- } \\
\text { bility (fraud). }\end{array}$ & $\begin{array}{l}\text { 8. Written Contract: } \\
\text { adhesion, terms were } \\
\text { not read or under- } \\
\text { stood, drafter in- } \\
\text { cluded terms that } \\
\text { were not reasonably } \\
\text { anticipatable. }\end{array}$ \\
\hline
\end{tabular}

The matrix illustrates the ways in which the distinctions between "shared and unshared meaning" and "cooperative and strategic communications" can operate in the context of contractual communication. Strategic communication can involve shared meaning; cooperative communication can involve unshared meaning. But it is also the case that strategic contractual communication can operate via unshared meaning, and that cooperative communication can employ shared meaning.

\section{APPlication OF THE GENERAL THEORY TO CONTRACTUAL COMMUNICATION}

We are now in a position to apply what we have learned about communication in general and legal communication in particular to contractual communication. Our aim will be to investigate Kar and Radin's theory of shared contractual meaning and its implications for contract doctrine and theory.

Some readers may be puzzled by the extended discussion of legal communication in general in a response that focuses on contractual communication. After all, contract law is conventionally understood as a distinct and bounded doctrinal field - governed by a set of legal norms that are semiautonomous. If contract law is semiautonomous, then we might suppose that contractual communication can be understood without reference to the implications of the philosophy of language and theoretical linguistics for legal communication in general. These thoughts seem reasonable, but the view advanced in this Response is that they are fundamentally misguided. Contractual communication relies on the same mechanisms as other forms of written and oral communication. Without an appreciation of the semantic and pragmatic mechanisms that enable all linguistic communication, any attempt to theorize contract law will be impoverished.

Contractual communication relies on the same semantic and pragmatic mechanisms that enable ordinary face-to-face conversations. Indeed, some contracts are the products of face-to-face oral exchanges, and the legal effect of those exchanges is governed by the law of offer 
and acceptance. But many written contracts involve communicative situations that depart in important ways from a face-to-face conversation. In this regard, contractual communication resembles other forms of legal communication that involve complex multistage processes. Constitutions and statutes are drafted by one set of actors, proposed and debated by others, and ratified or enacted by legislatures or referenda. Written contracts may be drafted by lawyers who borrow language from contracts or models drafted by other lawyers. Understanding the complex multistage processes of legal communication in general is therefore an essential step toward an adequate theory of complex multistage contractual communication.

The investigation can begin by laying out a typology of the situations of contractual communication.

\section{A. The Situation(s) of Contractual (and Pseudo-Contractual) Communication}

Contract law is very flexible. There are many kinds of contracts and a huge variety of situations in which contractual communication occurs. To simplify our task, I will limit my examination of the situations of contractual communication to four prototypes.

I. Negotiated Oral Contracts. - The first prototype is a negotiated oral contract between individuals. Consider the following exchange between Ben, a homeowner, and Alice, a handyperson:

Ben: Can you fix the faucet?

Alice: Yep. Fifty.

Ben: Fifty dollars? Can you do it today?

Alice: Yep. Won't take more than a half hour.

Ben: Great. I'll get out of your way.

Alice: I'm going out to my truck to get some parts. Back in a minute.

Alice completes the work, says, "I'm done," and Ben pays Alice fifty dollars in cash, saying, "Thank you. That was fast."

Notice that in this exchange, the speech acts of offer and acceptance are less than fully explicit. Ben does not say, "I offer you fifty dollars to fix the faucet located in this bathroom by 5:00 p.m. today." Alice does not say, "I accept your offer." Nonetheless, Alice communicates an offer and Ben accepts. The semantic content of their exchange is supplemented by pragmatic enrichment. When Ben explicitly says "great," the impliciture is "I agree" or "I accept your offer to do the work for fifty dollars in 30 minutes." Both Ben and Alice are able to convey their communicative intentions based on their shared understanding of the communicative situation.

2. Form Contracts Adopted by Sophisticated Parties. - The second prototype is a form contract adopted by sophisticated parties to handle a routine transaction. One example of such a contract is the Master 
Power Purchase \& Sale Agreement ("Master Contract") drafted by Edison Electric Institute (EEI) to govern wholesale purchases and sales of electricity. ${ }^{79}$ The Master Contract is forty-three pages in length and includes complex terms expressed using technical terminology. ${ }^{80}$ The Master Contract was drafted by a working group, described as follows:

The [EEI] Contract Working Group (CWG) is a broad group of market participants that includes risk managers and other stakeholders who are interested in providing input to the [EEI Contract Drafting Committee $(\mathrm{CDC})]$ and staying abreast of its activities. Both the CDC and CWG include representation not just from shareholder-owned utilities but all market participants (e.g., coops, banks and marketers, as well as outside counsels). ${ }^{81}$

The actual process of drafting the Master Contract in the EEI Contract Drafting Committee may be opaque to parties who employ the Master Contract. But they understand that the contract was drafted for a particular purpose with a particular set of readers in mind. ${ }^{82}$ The Master Contract reads as a document that was drafted to be comprehensible to the lawyers and sophisticated players who are employed by the corporate entities that enter into such agreements and to lawyers and judges who may become involved if a dispute arises and results in litigation. ${ }^{83}$

In actual practice, the Master Contract may or may not result in shared meaning. For example, if a set of contracting parties have relied on the Master Contract in a series of transactions over time, it is possible that the various agents and employees who employ the contract have changed. At $T_{I}$, it might have been the case that all of the key players for all of the parties had actually read the Master Contract and hence that the communicative intentions of the drafters (the EEI Contract Drafting Committee) were successfully conveyed to the responsible agents of the contracting parties. Suppose that at $T_{2}$, the Master Contract is modified by the EEI Contract Drafting Committee, perhaps in response to the recognition of a problem in the original Master Contract. At $T_{3}$, however, it might be the case that some of the key players have been replaced by others who have not actually read all of the revised Master Contract - indeed, they might be unaware of the changes from the original version. In this situation, the communicative intentions of the drafters may not have been conveyed to the responsible

\footnotetext{
79 Master Contract, EDISON ELECTRIC INST., https://www.eei.org/resourcesandmedia/ mastercontract/Pages/default.aspx [https://perma.cc/8CXD-WDF9].

80 Master Power Purchase \& Sale Agreement, Edison Electric Inst. (Apr. 25, 2000), https://www.eei.org/resourcesandmedia/mastercontract/Documents/contractooo4.pdf

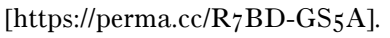

81 Working Group and Contract Drafting Committee, EDISON ELECTRIC INST., https://www.eei.org/resourcesandmedia/mastercontract/Pages/WorkingGroupandContract DraftingCommittee.aspx [https://perma.cc/B8LF-U6AN].

82 See Master Contract, supra note 79 (explaining the purpose and goals of the Master Contract).

83 See Master Power Purchase \& Sale Agreement, supra note 80, at 6-I I.
} 
agents of one or more of the parties. It is at least possible that the Master Contract might be adopted without any of the agents of any of the parties having fully grasped the communicative content of the contract. The meaning of the Master Contract may be accessible to the responsible agents of all the parties without actually bringing "shared meaning" into existence.

3. Negotiated Complex Agreements Between Business Entities. The third prototype is a negotiated complex agreement between business entities. Unlike the second prototype, which involved an "off-theshelf" Master Contract, the third prototype involves clause-by-clause negotiation involving lawyers and other agents of the business entities. Of course, clause-by-clause negotiation does not require the parties to start from scratch. A bespoke contract may involve reuse of contractual language from prior agreements. Standard clauses and phrases may be combined in new ways with language that is created for the particular occasion. Standard contractual provisions are sometimes called "boilerplate." 84

Boilerplate contractual language is common because of the advantages it offers to contracting business entities. Ready-to-wear business suits from Men's Wearhouse are cheaper than bespoke garments from Savile Row: boilerplate is less expensive than custom-tailored contractual language. Boilerplate that has generated judicial interpretations may come to have a standardized legal meaning and hence lead to predictable outcomes. As Professors Stephen Choi, Mitu Gulati, and Robert Scott explain:

Boilerplate terms are ubiquitous in commercial contracting because they offer the efficiency advantages of standardization. Those advantages include the development of a uniform system of communication that is independent of any particular contractual context. Thus, parties in heterogeneous environments who wish to communicate a shared intent can embody that intent in a fixed and reliable formulation whose meaning does not vary with the nature of the contract or its context. ${ }^{85}$

The process of contractual communication involving boilerplate is complex. A boilerplate clause is initially drafted by a lawyer and included in a contract. The clause becomes accessible to other lawyers, perhaps because it is discussed and interpreted in a judicial opinion. The clause is then incorporated by other lawyers in new contracts, which in turn are copied again. This process may result in communicative content that is stable over time and shared by relevant agents of the parties and by judges who interpret the language when disputes arise. In such cases, the communicative intentions of the original drafter are

\footnotetext{
84 For discussion of boilerplate, see generally MARgaret JANE RAdIN, BOILERPLATE: The Fine Print, VANishing Rights, AND the Rule of LAW (20I3); and Stephen J. Choi, Mitu Gulati \& Robert E. Scott, The Black Hole Problem in Commercial Boilerplate, 67 Duke L.J. I (20I7).

85 Choi, Gulati \& Scott, supra note 84 , at 4-5 (footnote omitted).
} 
successfully grasped by readers who reuse the text and successfully convey these communicative intentions to yet other readers.

But this is not necessarily the case. When boilerplate is originally drafted, the situation of contractual communication is bounded: a clause is written in the context of a particular transaction for the parties and possibly for the judges who might be called upon to interpret the text in the case of a dispute. But when the text is reused, the communicative situation is transformed and hence the communicative content of the clause may change over time. Such changes are not particularly problematic if the parties to a new contract incorporating old boilerplate communicate successfully, but there is no guarantee that boilerplate will result in shared meaning. The meaning of a boilerplate provision drafted at $T_{I}$ for Contract One may not carry over to Contract Two at $T 2$. The words may be the same while the meaning is different - same text, different communicative content.

Choi, Gulati, and Scott discuss the extreme case, in which a boilerplate clause utterly fails to create shared communicative content:

But standardized terms in boilerplate contracts between sophisticated parties are vulnerable to misinterpretation. At the limit, a boilerplate term that is reused for decades and without reflection merely because it is part of a standard-form package of terms, can be emptied of any recoverable meaning: this creates a contractual black hole. More commonly, terms that have lost much meaning still may provoke litigation over essentially meaningless variations in the boilerplate language. In this latter case of contractual grey holes, courts may be functionally incapable of devising a plausible meaning that was attached to the linguistic variations at the time the contract was drafted. Thus, regardless of whether a boilerplate term has lost all or only almost all meaning, courts will face an interpretation conundrum that we collectively term the "black hole" problem. ${ }^{86}$

The key to understanding the black hole problem is the realization that a boilerplate clause can be copied mechanically, without the drafter forming a communicative intention. This problem comes into particularly clear focus in the context of "cut and paste" drafting, where a lawyer might draft a contract by electronically copying text and pasting it into a new contract without even reading the clause. In such a case, the drafter of the contract has no first-order communicative intentions of their own - although the drafter might formulate a second-order communicative intention to adopt some prior understanding (such as the communicative intention of the original drafter or the shared meaning that the clause had for the parties to the prior contract). ${ }^{87}$

One famous example of the reuse of standard contractual language is the "pari passu" clause included in sovereign debt agreements. "Pari

86 Id. at 3-4 (footnotes omitted).

87 On second-order communicative intentions, see infra section II.D, pp. 66-67. 
passu" is Latin and could be translated literally as "with even step." 88 The phrase appears in clauses like this: "The Notes rank, and will rank, pari passu in right of payment with all other present and future unsecured and unsubordinated External Indebtedness of the Issuer." 89

The conventional understanding of such clauses was that the Notes (debt instruments) "were intended to stand on the same level footing without preference or priority among themselves." Choi, Gulati, and Scott argue that pari passu clauses no longer have clear communicative content:

[T] [he [contemporary meaning of the] pari passu clause, a boilerplate formulation common to sovereign debt contracts for nearly 200 years . . . [is] hopelessly unclear. The recent history of judicial interpretation of this clause began in Brussels in a case against the Republic of Peru in September 2000, in which a court issued the first interpretation of the clause in at least a half century. The same interpretation of pari passu was affirmed by a federal court in New York in a case against the Republic of Argentina in December $20 \mathrm{II}$, and affirmed again on appeal in that same case in October $20 \mathrm{I} 2$ and August 2013. In each of these cases, the courts endorsed an interpretation of a particular variation of pari passu that required holdout creditors to be paid in full as a condition to the sovereigns paying consenting creditors under a restructuring agreement. Even though this interpretation effectively undermined efforts by sovereigns to restructure their bonds, and even though the courts' interpretation was widely vilified in the market, meaningful revisions to the language of the boilerplate term did not even begin to appear until late $2014 .{ }^{91}$

If the story told by Choi, Gulati, and Scott is correct, pari passu clauses failed to create shared meaning. The drafters of sovereign debt agreements may not have given much thought to the meaning of the clause or they may have mistakenly assumed the clause would receive a judicial construction in line with the expectations of the parties to sovereign debt agreements.

The pari passu clause example illustrates the importance of attending to the actual situation of contractual communication. On the surface, a complex negotiated contract between business entities seems to resemble a face-to-face negotiated oral contract, but the surface appearance is misleading. In the first prototype (Ben and Alice negotiating a faucet repair), ${ }^{92}$ communicative intentions are successfully conveyed, resulting in the acceptance of an offer and the creation of a contract. But in the

\footnotetext{
88 Google Translate, GoOGLE, https://translate.google.com/\#view=home\&op= translate\&sl=la\&tl=en\&text=pari\% 2 opassu [https://perma.cc/5 $\left.\mathrm{LP}_{3}-\mathrm{CK} 8 \mathrm{~J}\right]$.

89 Lee C. Buchheit \& Jeremiah S. Pam, The Pari Passu Clause in Sovereign Debt Instruments, 53 EMORY L.J. 869, 87 I (2004).

90 Francis BeAufort PAlMer, Company PRECEDENTS i io (8th ed. i902).

91 Choi, Gulati \& Scott, supra note 84, at 6 (footnotes omitted).

92 See supra section II.A.I, p. 46.
} 
case of boilerplate clauses that create "black hole problems," the drafter does not have the requisite first-order communicative intentions: the negotiations fail to produce shared communicative content.

4. Contracts of Adhesion. - The fourth prototype is a contract of adhesion between a business entity and a consumer. One example of such an agreement is the "Google Terms of Service," 93 to which users may agree when they first use various Google services, such as Gmail, ${ }^{94}$ Google Calendar, ${ }^{95}$ or Google Drive. ${ }^{96}$ A contract of adhesion is a standard form contract that is offered on a take-it-or-leave-it basis: by definition a contract of adhesion is not negotiated. ${ }^{97}$ The Google Terms of Service agreement is a contract of adhesion, because the terms are standard and nonnegotiable. I haven't actually tried to negotiate with Google over the terms of service, but I am willing to bet that any such attempt would be unsuccessful: Google offers Gmail on a "take-it-or-leave-it" basis.

The Google Terms of Service are relatively short, although they contain cross references to other terms, such as Google's "Privacy Policy." 98 My impression is that the Google Terms of Service are mostly written in clear and concise language that can be understood by competent speakers of standard American English, but some provisions do incorporate legal terms of art. Here are some examples:

93 Google Terms of Service, GoOGLE (Oct. 25, 20I7), https://policies.google.com/terms?hl= en-US [https://perma.cc/WSL9-RXHZ].

94 Get More Done with Gmail, GOOGLE, https://www.google.com/gmail/about [https://perma.cc/7 KDC-5 ULK].

95 Google Calendar, GOOGLE, https://calendar.google.com/calendar [https://perma.cc/Y534M6LC].

96 Google Drive, GooGLE, https://google.com/drive [https://perma.cc/H9T7-S6W 3 ].

97 Professor Todd Rakoff offers the following definition:

(I) The document whose legal validity is at issue is a printed form that contains many terms and clearly purports to be a contract.

(2) The form has been drafted by, or on behalf of, one party to the transaction.

(3) The drafting party participates in numerous transactions of the type represented by the form and enters into these transactions as a matter of routine.

(4) The form is presented to the adhering party with the representation that, except perhaps for a few identified items (such as the price term), the drafting party will enter into the transaction only on the terms contained in the document. This representation may be explicit or may be implicit in the situation, but it is understood by the adherent.

(5) After the parties have dickered over whatever terms are open to bargaining, the document is signed by the adherent.

(6) The adhering party enters into few transactions of the type represented by the form - few, at least, in comparison with the drafting party.

(7) The principal obligation of the adhering party in the transaction considered as a whole is the payment of money.

Todd D. Rakoff, Contracts of Adhesion: An Essay in Reconstruction, 96 HARV. L. REV. I I 73, I I 77 (1983) (footnote omitted).

98 Google Privacy Policy, GoOGLe (Oct. I5, 20I9), https://policies.google.com/privacy?hl= en-US [https://perma.cc/U $\left.7 \mathrm{HD}-\mathrm{YJ}_{4} \mathrm{~W}\right]$. 
Some of our Services allow you to upload, submit, store, send or receive content. You retain ownership of any intellectual property rights that you hold in that content. In short, what belongs to you stays yours.

SOME JURISDICTIONS PROVIDE FOR CERTAIN WARRANTIES, LIKE THE IMPLIED WARRANTY OF MERCHANTABILITY, FITNESS FOR A PARTICULAR PURPOSE AND NON-INFRINGEMENT. TO THE EXTENT PERMITTED BY LAW, WE EXCLUDE ALL WARRANTIES.

The laws of California, U.S.A., excluding California's conflict of laws rules, will apply to any disputes arising out of or relating to these terms or the Services. All claims arising out of or relating to these terms or the Services will be litigated exclusively in the federal or state courts of Santa Clara County, California, USA, and you and Google consent to personal jurisdiction in those courts. ${ }^{99}$

I don't know who drafted the text of the Google Terms of Service, but it seems plausible (and perhaps likely) that they were drafted by Google's in-house lawyers. Perhaps an initial draft was written and edited, with subsequent versions edited by the original drafters or by new lawyers who were not part of the original drafting process. It seems quite likely that any particular posted version of the Google Terms of Service was actually read and understood by some lawyer who approved the final version. Once again, we have a multistage process of communication, in which the communicative intentions of the drafters of various clauses are conveyed to others who participate in the drafting process. The drafters likely understand that the terms they write will sometimes be read by Google users and may also be read by lawyers and judges if disputes arise.

\section{B. The Idea of Shared Meaning}

The discussion that follows interrogates Kar and Radin's notion of "shared meaning." What is required for "meaning" to be "shared"? How does shared meaning relate to the Gricean notion of speaker's meaning and Austin's idea of a speech act? The discussion that follows suggests two distinct conceptions of "shared meaning" before turning to an indepth investigation of Kar and Radin's version.

I. "Shared Meaning" as Successfully Communicated Content and Force. - Contractual communication can be explicated via Kar and Radin's idea of "shared meaning," the Gricean notion of communicative intentions, and Austin's idea of illocutionary force. For example, in negotiated oral contracts, the parties create shared meaning if they are able to successfully convey their communicative intentions. Notice that success requires mutual recognition of both the content and force of the offer and the acceptance. Mutual recognition of content requires that the offeror's communicative intention to offer particular terms (content)

99 Google Terms of Service, supra note 93. 
be successfully conveyed to the offeree - and that these terms be recognized by the offeree as the speech act of offering (force).

These abstract ideas are illustrated by Raffles v. Wichelhaus, ${ }^{100}$ commonly known as the ship "Peerless" case. Judge Mellish explained:

There is nothing on the face of the contract to shew that any particular ship called the "Peerless" was meant; but the moment it appears that two ships called the "Peerless" were about to sail from Bombay there is a latent ambiguity, and parol evidence may be given for the purpose of shewing that the defendant meant one "Peerless" and the plaintiff another. That being so, there was no consenus [sic] ad item, and therefore no binding contract. ${ }^{101}$

The report is brief and does not include a narrative of offer and acceptance, but the following account seems plausible. There is no dispute about the illocutionary force of the offer and acceptance. Both parties agreed that there was an attempt to enter into agreement; the communicative intentions to engage in the speech acts of offering and accepting were successfully conveyed. Nonetheless, the communication misfired because the content of the offer contained a proper name ("Peerless") that had two possible referents, the two ships that had the name "Peerless." 102 The offeror failed to successfully convey the content of their offer to the offeree.

Contractual communication can misfire for a different reason: the communicative intention to convey a particular illocutionary force can misfire. A communication not intended to have the force of an offer might nonetheless be understood as such. ${ }^{103}$ A communication not intended to have the force of an acceptance might be misconstrued as an acceptance. Successful contractual communication requires mutual recognition of both content and force.

Contractual communication can fail, but it can also succeed. When the communicative intentions of an offeror with respect to both force and content are successfully communicated to an offeree who then

100 (I864) I59 Eng. Rep. 375; 2 Hurl. \& C. 906. See generally A. W. Brian Simpson, Contracts for Cotton to Arrive: The Case of the Two Ships Peerless, i I CARDOzo L. REV. 287 (I989).

101 Raffles, I59 Eng. Rep. at 376.

102 Raffles involved a proper name, but the same problem can arise with respect to terms that represent some general concept or kind of thing. Thus, in Indiana Fuel Supply Co. v. Indianapolis Basket Co., 84 N.E. 776 (Ind. App. I908), the offeror and offeree had different understandings of the phrase "egg coal":

If in this case the terms of the contract entered into by the parties would properly describe domestic egg coal, and could be understood by either of the parties as meaning domestic egg coal, and would also describe steam egg coal, and could be understood by either of the parties as meaning steam egg coal, and one of them had in mind when he contracted for egg coal the higher grade of coal, and the other had in mind when entering into the contract the lower grade of coal, and each party believed that by the terms of the contract he was contracting for the particular kind of coal he had in mind, then no contract was entered into between the parties.

Id. at 777; see also William F. Young, Jr., Equivocation in the Making of Agreements, 64 CoLUM. L. REV. 6I9, 625 (I964) (discussing Indiana Fuel, Raffles, and similar cases).

103 See Tiersma, supra note 42, at 225; see also Lawrence M. Solan, Contract as Agreement, 83 Notre DAME L. REV. 353, 36I (2007). 
successfully conveys both the force and content of an acceptance, the result could be called "shared meaning." In negotiated oral contracts, communicative intentions may be conveyed semantically by explicit statements, but this is not required, because an offer or acceptance may be conveyed implicitly as a result of pragmatic enrichment. The first interpretation of the idea of shared meaning is successfully communicated content and force that results in an actual agreement between the parties.

Notice, however, that outside of negotiated oral contracts, the parties may view themselves as having entered into a contract despite the fact that the full content of the agreement is not actually shared. Consider the following scenarios:

Scenario One: The parties to a complex transaction use a standard form agreement (such as the EEI Master Contract) without realizing that one of the salient terms in the form has changed since the last time at which agents of the parties thoroughly vetted the form. When the parties enter into the agreement they have a shared understanding of the illocutionary force of their communications (for example, offer and acceptance), but neither party's agents actually comprehend the full content of the form.

Scenario Two: The parties to a complex transaction negotiate a bespoke agreement without realizing a particular boilerplate clause has a standard meaning with legal consequences to which they would not have agreed (such as the pari passu clause that was contained in many sovereign debt agreements). Again, there is a shared understanding of illocutionary force, but neither party's agents actually comprehend the content of the clause.

Scenario Three: The consumer who agrees to a contract of adhesion (such as the Google Terms of Service) does not read the agreement but understands that they are agreeing to something that they have chosen not to read. Again, there can be mutual understanding of force, but the content of the agreement is only understood by the agents of the business entity.

In each of these examples, there is no "shared meaning" if we understand shared meaning to require the successful communication of both force and content. In Scenarios One and Two, the conventional understanding would be that the parties have entered into a contract despite the absence of "shared meaning" in the sense of successfully communicated force and content. Scenario Three is open to dispute: perhaps there is a contract, perhaps not.

If "shared meaning" requires successful communication of both force and content and if "shared meaning" is required for "contract," then the agreements in Scenarios One, Two, and Three are not "contracts" and should instead be denominated "pseudo-contracts" (Kar and Radin's terminology). On the other hand, perhaps one or more of these scenarios should be understood as involving proper "contracts." If so, that would 
raise a question about either the nature of "shared meaning" or the requirement that an agreement involve "shared meaning" in order to be properly denominated a "contract." What happens if we propose a less stringent understanding of "shared meaning"?

2. "Shared Meaning" as Reasonably Accessible Content and Successfully Communicated Force. - Consider a second possibility. We might understand "shared meaning" as extending to cases in which illocutionary force is successfully communicated and content is either successfully communicated or is reasonably accessible to both parties. The second understanding of "shared meaning" relies on the notion of "reasonably accessible content." The basic idea here is that content can be accessible but not yet accessed. That idea should be uncontroversial. In written communication, it is almost always the case that content is created before it is actually conveyed. ${ }^{104} \mathrm{~A}$ draft contract has content before the draft is read by someone other than the drafter.

Scenario One ${ }^{105}$ involves content that is reasonably accessible to both parties but is not actually communicated. In Scenario One, the EEI Master Contract could be understood by the agents of the parties. Because the lawyers for the parties could read and comprehend the content of the agreement with the usual amount of effort required, the content of the Master Contract is "reasonably accessible" as I am using that phrase. So, if "shared meaning" is understood in this way and if "shared meaning" is required for "contract" (as opposed to pseudo-contract), then the Master Contract is a true "contract."

Scenario Two ${ }^{106}$ may be different. If pari passu clauses have a "black hole problem," 107 then the content of a contract containing such clauses may not be reasonably accessible to either party. There may be other provisions of the contract with successfully communicated content or with reasonably accessible content, but the full communicative content of the agreement contains a gap. We might be tempted to say that such an agreement is not a true "contract," but there are other possibilities. We might say that the pari passu clause has no legal effect, creating a gap that must be filled, either by an off-the-shelf default rule or a bespoke provision created by judicial construction.

3. Kar and Radin's Understanding of "Shared Meaning." - I now turn to Kar and Radin's explication of the idea of "shared meaning." Here is their initial definition of "shared meaning":

104 There are possible situations in which content is conveyed as it is being created. For example, if someone were to be looking over my shoulder as I wrote this Response, content creation and conveyance would be simultaneous - as is ordinarily the case in face-to-face oral communication.

105 See supra section II.B.I, p. 54.

106 See supra section II.B.I, p. 54.

107 Choi, Gulati \& Scott, supra note 84 , at 3-4. 
We ... define the "shared meaning" of a contract as the meaning parties produce and agree to during contract formation that is most consistent with the presupposition that both were using language cooperatively to form a contract. ${ }^{108}$

This definition cannot be what Kar and Radin would endorse upon reflection. The definition contains two elements:

Element One: "[T]he meaning parties produce and agree to during contract formation."

Element Two: "[T]he meaning . . . that is most consistent with the presupposition that both were using language cooperatively to form a contract."

When both elements are satisfied, this definition is very close to the first formulation above - "successfully communicated content and force." Their definition implicitly assumes that the intended force of the communications (for example, offer and acceptance) was to create a contract. When content is successfully communicated and the parties are engaging in cooperative contractual communication, then both Elements One and Two are satisfied.

But Elements One and Two can come apart in a variety of ways. Element Two assumes cooperative contractual communication, but contracting parties can engage in strategic communication that nonetheless produces shared understandings of communicative content - as illustrated in Table I. ${ }^{109}$ In such cases, the content that would have been produced by cooperative communication may diverge from the content that was actually shared. ${ }^{110}$

Another source of possible divergence is illustrated by Scenario One, in which the parties agree to the EEI Master Contract but do not actually comprehend its terms. Are the unnoticed terms part of "the meaning parties produce and agree to during contract formation"? 111 Here,

\footnotetext{
108 Kar \& Radin, supra note I, at I I 43.

109 See supra Table I.

110 Elements One and Two might be intended to express necessary and sufficient conditions for shared meaning. That is, for meaning to be shared it must both be produced and agreed to during contract formation, and it must also be maximally consistent with the presupposition that both parties were using language cooperatively to form a contract. If this understanding is correct, then failure to satisfy either element results in a lack of shared meaning. For example, a contract that violated the maxim of quantity by containing redundant provisions would lack "shared meaning" even if both parties understood the redundant provisions. Similarly, a contract that satisfied all the maxims would lack shared meaning if one or more of the parties failed to grasp its content. In any event, this interpretation of the second definition is inconsistent with its actual wording: "We then define the 'shared meaning' of a contract as the meaning parties produce and agree to during contract formation that is most consistent with the presupposition that both were using language cooperatively to form a contract.” Kar \& Radin, supra note I, at I 43 (emphasis added). The italicized portion of the definition is not a conjunction: shared meaning is agreed meaning "that is most consistent" with the specified presupposition. Id.

$111 I d$. (emphasis added).
} 
my reaction is that Kar and Radin's notion of "produce and agree" 112 is ambiguous, with at least two possible interpretations.

Consider the first interpretation of "produce and agree." Production and agreement might simply mean that the parties somehow produced a text and then agreed to be bound by the standard meaning (Gricean sentence meaning) of that text. This first interpretation of their definition would entail that the terms of the EEI Master Contract are "shared meaning" - assuming that the terms of the Master Contract are consistent with cooperative contractual communication. ${ }^{113}$

Or they might require that the parties produce and agree to the actual meaning (communicative content) of the contract. On this second interpretation of "produce and agree," the EEI Master Contract would not satisfy Element One, but it might still satisfy Element Two revealing the potential inconsistency between Element One and Element Two. Kar and Radin use expressions like "a shared meaning to which both parties actually agreed." 114 Their use of this expression seems to support the second interpretation. And Kar and Radin seem to explicitly reject the first interpretation when they state, "delivery of text is not the same thing as successful production of shared meaning for a contract." 115

The second interpretation of "produce and agree" also seems to be supported by their analysis of boilerplate terms: "'terms' - which now include enormous streams of boilerplate text that are delivered but never read by anyone - are no longer terms with shared meaning." ${ }^{16}$ And the second interpretation is also supported by the footnote to their definition, which reads as follows:

The common meaning of the parties cannot be discerned if the only factor considered is what a sentence would mean to a competent language speaker, regardless of whether it was ever cooperatively communicated. This approach is sometimes dubbed "objective." A contract also cannot be properly interpreted based on a deviant interpretation held secretly by one party.

This approach is sometimes labeled "subjective."117

The emphasis in this passage is on what is "communicated," suggesting that actual communication of content is required by the phrase "the meaning parties produce and agree to during contract formation." 118

$112 I d$.

113 The first interpretation relies on the distinction between first- and second-order communicative intentions that is discussed below. See infra section II.D, pp. 66-67. On the first interpretation, it is sufficient for the parties to have a meshing second-order communicative intention - specifically, the intention to be bound by the standard or ordinary meaning of the words.

114 Kar \& Radin, supra note I, at I I39 (emphasis added).

115 Id. at I 155 .

116 Id. at I I 40.

117 Id. at I I 43 n.I 8.

$118 I d$. at I I 43 . 
How could Kar and Radin resolve the tension between Element One and Element Two of their proposed definition? One possibility is that "shared meaning" is actually defined by Element Two. That possibility is suggested by a second definition of "shared meaning" offered at a later point in their article: "The shared meaning of a contract is the meaning that is most consistent with the presupposition that both parties were using language cooperatively to form a contract." ${ }^{119}$ The second definition omits Element One.

At this point, it is important to observe that there is a deep difference between the second interpretation of Element One (requiring communicative content that is actually shared) and Element Two as reflected in Kar and Radin's second definition. Element One limits the terms of a contract to those that actually were shared. Element Two and the second definition involve meaning that is potentially counterfactual. The meaning that is most consistent with using language cooperatively may or may not be the same as the meaning that was actually shared.

The key to understanding the second definition is the phrase "most consistent with cooperative contractual communication." What does this mean? The answer comes in Kar and Radin's third definition of "shared meaning":

The "shared meaning" of a contract can now be defined at a suitable level of generality as that meaning that is most consistent with the presupposition that both parties were using language cooperatively to contract that is, in accordance with the four relevant Maxims of Quantity, Quality, Relation, and Manner, and any further specifications of them. The shared meaning of a contract differs from both sentence meaning and any one party's speaker meaning. ${ }^{120}$

The third definition cashes out the idea of shared meaning in terms of consistency with Grice's maxims of conversation.

In some cases, the meaning that is most consistent with the maxims will be the communicative content that is actually shared by the parties, but in other cases the content that would be most consistent with the maxims of conversation will be different from the content that was actually shared.

Let us give a name to Kar and Radin's third definition, which glosses "shared meaning" as the meaning that is most consistent with the maxims:

Maxim Maximizing Meaning is the communicative content that would have been produced if the parties to an agreement had

119 Id. at I 146.

$120 \mathrm{Id}$. at I I 54. The third definition is clearly distinct from the second. Whereas the second definition contains two elements, the third definition (as stated) contains only one. It is possible that the third definition is phrased badly and that Kar and Radin actually intended the third definition as a gloss on the second element of the second definition. This possibility leaves the tension between the two elements of the second definition without explicit resolution. See supra note i Io. 
communicative intentions and understandings that were maximally consistent with the maxims of conversation.

And let us define the contrasting notions of actually shared meaning and actual meanings that are not shared.

Shared Actual Meaning is the communicative content that results if communicative intentions are successfully conveyed in contractual communication. For example, if both the content and force of an offer are successfully communicated by an offeror and an offeree successfully communicates the content and force of an acceptance, then the communicative content of the resulting agreement is Shared Actual Meaning.

Unshared Actual Meanings are the communicative contents that result if the communicative intentions are misunderstood in contractual communications. For example, if the content of an offer is not successfully communicated by an offeror resulting in an offeree grasping content that is different, then the resulting "contract" has Unshared Actual Meaning - as in Raffles v. Wichelhaus. ${ }^{121}$

Finally, let us add a definition for meanings that are reasonably accessible to the parties to an agreement, but are not actually shared:

Reasonably Accessible Meaning is the communicative content that would result if the communicative intentions of the drafters of contractual language had been successfully conveyed to the contracting parties (whether or not the drafter is a party) if and only if these communicative intentions were reasonably accessible to the parties in due course.

With these four stipulated definitions in place, we are now in a position to undertake a more precise analysis of the conceptual structure of Kar and Radin's shared meaning theory.

Maxim Maximizing Meaning can be identical to Shared Actual Meaning - as in the case of a negotiated oral contract in which the behavior of the parties conforms to the maxims of conversation: a successfully negotiated oral agreement like the one between Ben and Alice discussed above is an example of such identity. ${ }^{122}$ But this need not be the case. In some cases, the Maxim Maximizing Meaning will be identical to the Reasonably Accessible Meaning - as may be the case in the hypothetical in which parties agree to the EEI Master Contract but are unaware of some new terms (and hence lack Shared Actual Meaning). ${ }^{123}$ In other cases, the Maxim Maximizing Meaning will be one of the Unshared Actual Meanings that arise when contractual communication misfires: if the offeror's communicative intentions are more consistent with the maxims than the offeree's understandings of those intentions, then the offeree's intentions are the Maxim Maximizing Meaning — and vice versa if the offeree's understandings are more consistent with the maxims.

\footnotetext{
121 (I864) I59 Eng. Rep. 375; 2 Hurl. \& C. 906.

122 See supra section II.A.I, p. 47.

123 See supra section II.A.2, p. 47.
} 
My investigation of Kar and Radin's idea of "shared meaning" suggests that this notion is not a simple one. Shared Actual Meaning, Reasonably Accessible Meaning, and Maxim Maximizing Meaning are conceptually distinct and sometimes diverge in application. The next step in my investigation is to examine Kar and Radin's application of the Shared Meaning Analysis to problems of contract law.

\section{Shared Meaning and Contract Construction}

How does Shared Meaning Analysis play out in contract law? This question marks an important conceptual move from the discussion of the nature of "shared meaning." When we ask questions about the legal effect that courts will give to contractual communications, we turn from interpretation (the discovery of communicative content) to construction (the determination of legal effect). Kar and Radin believe that Shared Meaning Analysis enables us to differentiate between contract and pseudo-contract. ${ }^{124}$ When courts ask the question, "What are the terms of a contract?," they should limit their answer to those terms which are part of the shared meaning of the contract. How would this work in practice? And how does Shared Meaning Analysis handle divergence between Shared Actual Meaning, Reasonably Accessible Meaning, and Maxim Maximizing Meaning? Kar and Radin investigate these questions in a variety of contexts, but I will limit my discussion to two specific contexts: boilerplate and fine print.

I. Shared Meaning and Boilerplate. - How should the law treat boilerplate? Kar and Radin's analysis of boilerplate begins with a test that requires judges to perform a thought experiment:

We suggest that courts imagine that all of the written and digital text exchanged during contract formation is converted into oral form and takes place in a face-to-face conversation between the relevant parties. With respect to any disputed boilerplate text, courts can then ask the following question:

Could this boilerplate text have plausibly contributed to an oral conversation that contributes terms to a contract consistent with the presupposition that both parties were observing the cooperative norms that govern language use to form a contract? ${ }^{125}$

The thought experiment involves a counterfactual - an oral conversation in which the string of words constituting the boilerplate is read out loud. The thought experiment asks whether the boilerplate would have created shared communicative content in an oral exchange.

Kar and Radin contend that this thought experiment can be used to identify "shared meaning," but when they describe the work they believe the test will perform, they shift from the language of counterfactuals to the language of actual agreement. Here is the key passage:

\footnotetext{
124 See Kar \& Radin, supra note I, at II $42-43$.
}

125 Id. at I 67 . 
The first question that the conceptual test of [S]hared [M]eaning [A]nalysis can help courts answer more accurately is whether any disputed piece of boilerplate text contributes to an actual agreement between parties. Actual agreement is a boundary line. Without any actual agreement, there is no contract; whereas any boilerplate text that falls within the scope of parties' actual agreements adds terms to a contract that are presumptively legally enforceable. Actual agreements also have content, which is identical to the common meaning of the parties. This has implications for the scope of parties' actual agreements and contracts. ${ }^{126}$

Given our investigation of the nature of "shared meaning," there is reason to be concerned about the apparent tension between the counterfactual nature of the thought experiment and the work that it is supposed to do - determining "actual agreement" and "the common meaning of the parties."

We can examine this tension by considering one of their examples and contrasting it with the second prototypical situation of contractual communication introduced above, the EEI Master Contract. ${ }^{127}$ Kar and Radin discuss similar agreements in the following passage, with an important sentence highlighted (by me) in italics:

How does [S]hared [M]eaning [A]nalysis relate to boilerplate text required of members in particular businesses or trade associations? Many of the issues posed by boilerplate that is generated by trade associations are not issues of contract scope or interpretation. For example, the requirement of some industry-wide boilerplate terms could be anticompetitive under certain (perhaps many) circumstances - creating ensconced collusion and making new entry into the market difficult or economically impossible (too risky, or otherwise too expensive). Still, the participants in associations like these are typically sophisticated parties who understand and even play a role in producing changes from time to time to the required boilerplate text. Though the linguistic interactions are more complex, it is possible to understand most or all of this boilerplate text as contributing to a longer-term oral conversation in which the text is actually conveyed and understood at some point by most or all of the relevant sophisticated parties. So unlike in the case of consumer clickwrap purchases, there should be fewer problems with this type of high-end boilerplate creating actual agreements with shared meanings. Most disputes should be over how to interpret the shared meaning of this boilerplate text in social context, rather than over whether the boilerplate text contributes terms to the contracts. ${ }^{128}$

The italicized passage is illuminated by recalling the distinctions between Shared Actual Meaning, Unshared Actual Meaning, Maxim Maximizing Meaning, and Reasonably Accessible Meaning as defined above. ${ }^{129}$ Kar and Radin's counterfactual thought experiment is a vehicle for recovering Maxim Maximizing Meaning, but because it is a

126 Id. at I 73.

127 See supra section II.A.2, pp. 47-48.

128 Kar \& Radin, supra note I, at I I89 (emphasis added) (footnote omitted).

129 See supra section II.B.3, pp. 58-59. 
counterfactual it does not aim to recover Shared Actual Meaning, despite the misleading reference to "the text" being "actually conveyed and understood at some point by most or all of the relevant sophisticated parties."

Consider the implications of Kar and Radin's thought experiment for the hypothetical introduced in the discussion of the second prototypical situation of contractual communication. ${ }^{130}$ The EEI Master Contract would produce Shared Actual Meaning if it were read and understood by agents of the parties, but in the hypothetical, the agents of the contracting parties have not read and understood the most recent version of the agreement because they assume that it is the same as a prior version employed by the parties. Some of the terms in the EEI Master Contract are not "actually conveyed and understood" by either of the parties in the hypothetical.

If we understand Kar and Radin to require actual agreement on terms, then some of the provisions of the EEI Master Contract are not part of their contract. If we understand Kar and Radin to allow for terms to which there would have been agreement in a counterfactual oral exchange, then these provisions are part of the contract. But they cannot have it both ways.

There is another solution to this problem, which is suggested by the idea of Reasonably Accessible Meaning. We might take the position that the terms of the EEI Master Contract govern so long as they are either part of its Shared Actual Meaning or its Reasonably Accessible Meaning. That is, we could explicitly acknowledge the distinction between meaning that is actually shared and meaning that is reasonably accessible but not actually shared. This way of talking has one important advantage of conceptual clarity: it makes the distinction between actual sharing and reasonable accessibility clear and transparent.

Not explicitly acknowledging the distinction between Shared Actual Meaning and Reasonably Accessible Meaning has several disadvantages. The question whether a complex form contract would be comprehensible in an oral exchange is an empirical one. The answer depends on the findings of cognitive science regarding mental processing of information conveyed in oral exchanges. If those findings reveal that some complex written agreements can be understood in written form, but that their complexity is such that they cannot be conveyed in an oral exchange, Kar and Radin's test will reject their inclusion in the contract. But this result seems arbitrary. If we are after Shared Actual Meaning, communicative content that was accessed by all of the parties to a contract, then the question is whether the provisions of a written contract were understood as conveyed in writing. The fact that the provisions would not have been understood if they had been conveyed orally is simply not relevant to question whether they were actually shared.

130 See supra section II.A.2, p. 47. 
These issues are made more complex by the fact that Kar and Radin's test does not exclude all contractual provisions that did not produce Shared Actual Meaning. Without the double negative in the prior sentence, the point is that Kar and Radin would give legal effect to unshared meanings.

Provisions that pass the oral exchange test are part of a contract, even if they were not actually read and comprehended. So, the oral exchange test seems to allow for provisions that satisfy something that resembles the criterion of Reasonably Accessible Meaning. Perhaps Kar and Radin believe that access is reasonable if the terms would have been comprehended as part of an oral conversation. But why is an imaginary oral conversation the proper standard for what is reasonably accessible? If the parties could have understood the provisions in written form using effort that is proportionate to the stakes (for example, the monetary value of the agreement), then why should it matter whether the terms would have been understood in an oral exchange? For example, the EEI Master Contract might be comprehensible to lawyers who spend a reasonable amount of time studying its provisions in written form; this might involve rereading complex sentences and tracing the interaction between various provisions. Why should it matter if the provisions could not be understood in an oral conversation? So far as I can tell, Kar and Radin do not provide a normative defense of their oral conversation test.

2. Shared Meaning and Fine Print. - How should contract law treat fine print? Kar and Radin discuss this problem ${ }^{131}$ in the context of Izadi v. Machado (Gus) Ford, Inc. ${ }^{132}$ For my purposes the key fact of the $I z a d i$ case is that an offer in a newspaper to provide a $\$ 3000$ tradein value on any car was limited in "infinitesimally small print" to the purchase of two particular cars, neither of which was pictured in the advertisement. ${ }^{133}$ When Izadi attempted to purchase one of the cars that was pictured (a I988 Ford Ranger Pick-Up), he was informed of the fine print. ${ }^{134}$

Kar and Radin apply their imaginary oral contract test as follows:

Use of the conceptual test of [S]hared [M]eaning [A]nalysis suggests that oral communication of the ad would have conversationally implied without literally saying - that the $\$ 3,000$ minimum trade-in allowance applied to the purchase of a I988 Ford Ranger Pick-Up. When the car dealership tried to add an additional limitation, through "infinitesimally small print," one would have to imagine that an agent for the dealership proposed this additional limitation only inaudibly, under his breath. This proposed

\footnotetext{
131 Kar \& Radin, supra note I, at I I $92-95$.

132 550 So. 2d I I35 (Fla. Dist. Ct. App. I 989).

133 Kar \& Radin, supra note I, at I I93-94 (citing Izadi, 550 So. 2 d at I I38).

134 Id.
} 
limitation was not communicated clearly enough to comply with the Maxim of Manner - which says to communicate clearly. It therefore failed to contribute any proposed terms that were ever under discussion or actually agreed to when the parties formed their contract. ${ }^{135}$

This analysis is insightful, but it raises several questions. First, when the written offer is transposed into an oral conversation, Kar and Radin stipulate that the additional limitations were proposed "inaudibly" under the breath of the agent for the dealership. But this stipulation seems contrary to the general design of the thought experiment. Consider how this move might be transposed into another context, clickwrap agreements. We could just as easily imagine that clickwrap terms are delivered from a great distance so that they cannot be heard. If the fine print is truly incomprehensible because the print is so fine as to be unreadable (truly inaccessible or figuratively infinitesimal), then it is not part of the writing and we don't need the thought experiment to show this. If the fine print is legible, then it seems inappropriate to make it inaudible in the thought experiment. The more natural translation would be an oral communication that is delivered at a low volume that requires focused attention. The more general point is that the outcome of the thought experiment hinges on seemingly arbitrary decisions about how to translate the actual written communication into a hypothetical oral exchange.

In Izadi (or a hypothetical variation of its facts), the terms in fine print were not part of the Shared Actual Meaning of the offer, because the offeree, Izadi, did not read them. Were these terms nonetheless part of the Reasonably Accessible Meaning? The question is not whether it would have been possible for the offeree to access the term limiting the offer: presumably it was possible, although it might have required a magnifying glass. Rather, the question is whether the fine print was reasonably accessible: Could it have been understood by an ordinary person making an effort that is reasonable under the circumstances?

Perhaps, the problem is not that the consumer could not have read the fine print, but that we believe that it is unreasonable to require consumers to do this. Defining the standard for reasonable accessibility is beyond the scope of this Response, but it seems likely that a defensible conception of reasonable accessibility would result in the conclusion that the fine print limitation was not part of the reasonably accessible content of the agreement. For example, if the print was so fine that it could only be read by use of a magnifying glass, then we might conclude that it was not reasonably accessible.

But there is another aspect of Izadi that seems more fundamental. The advertisement appears to have been designed to be deliberately misleading. Even if a wary consumer could reasonably have accessed the 
fine print, the combination of the large print offer of a $\$ 3000$ trade-in on any vehicle with pictures of vehicles that were excluded by the fine print $^{136}$ supports the inference that the advertisement was intended to deceive consumers, luring customers into the dealership by creating the impression that they could get a $\$ 3000$ trade-in on their $\$ 500$ junker for the purchase of a desirable and reasonably priced Ford Ranger. This would be a classic "bait and switch." 137

The discussion of strategic and cooperative contractual communication above demonstrated the conceptual independence of the distinction between strategic and cooperative communication, on the one hand, and shared and unshared meaning on the other. ${ }^{138}$ Suppose that Izadi had actually read the fine print with the aid of a magnifying glass and understood the exclusion. The term would then have been part of the Shared Actual Meaning of the offer, but the offer would nonetheless have been a strategic contractual communication that aimed at deception but failed. The question whether we should nonetheless allow Izadi to enforce the offer as he would have understood it if he had been deceived is an interesting one, but the notion of shared meaning that is infact shared would not urge an affirmative answer.

There is another dimension of the Izadi case illuminated by the Gricean idea of speaker's meaning - the meaning the speaker or author intends the listener to grasp via the listener's or reader's recognition of the speaker's communicative intentions. In the Izadi case, it seems plausible that the dealership intended to communicate different messages to different readers and to the same readers on different occasions. Customers were intended to recognize one communicative intention at the time they initially read the advertisement (no limitation to the two particular models) and another communicative intention when the fine print was drawn to their attention when they proffered a trade-in on a model outside the limitation. This second communicative intention provided the meaning that the dealership hoped to convey to courts, if a consumer tried to hold the dealership to its offer. In other words, the dealership was speaking out of both sides of its mouth.

Under these circumstances, we might say that the limitation to two particular models was not part of the offer to Izadi. Izadi correctly grasped the dealership's communicative intentions directed to consumers: if Izadi then accepted the offer, Shared Actual Meaning would have been created. This can be true, even though the advertisement embodied multiple and inconsistent communicative intentions. The communicative intention conveyed to Izadi at the time he read the advertisement differed from the intention conveyed when the fine print

136 Izadi, 55 o So. $2 \mathrm{~d}$ at I I 37.

137 See David Adam Friedman, Explaining “Bait-and-Switch" Regulation, 4 WM. \& MARY BUS. L. REV. 575, 580-8I (2013) (defining "bait and switch").

138 See supra section I.B.3(c), p. 43. 
was pointed out. The text was the same; the communicative intentions conveyed by the text in distinct contexts were different. This feature of the Izadi case shows the importance of clearly distinguishing the semantics and pragmatics of contractual communication: the same text (the advertisement) produces different communicative content when read in different contexts.

In sum, I would like to suggest that cases like Izadi are more complex than Kar and Radin's analysis would suggest. Moreover, it is not clear that either Grice's maxims of conversation or the imaginary oral conversation thought experiment provides the most perspicuous analysis of cases involving strategic contractual communication. Even if we agree with Kar and Radin that Izadi should prevail, our reasons may differ from theirs.

\section{First-and Second-Order Communicative Intentions}

At this point, we can step back and examine an issue that has been lurking in the background so far. In the discussion of the "black hole problem" associated with pari passu clauses, I introduced the idea of "first-order" and "second-order" communicative intentions. ${ }^{139}$ This idea is well articulated by Professor Michael Moore: "An interpretive intent is a second-order intention about how one's first order intentions are to be used in interpreting what one has said." 140

Let us now stipulate the following definitions:

First-Order Communicative Intention: A first-order communicative intention is an intention to convey particular content via an utterance or writing. Example: Harry utters "Simon is beautiful" with the firstorder communicative intention to convey the proposition Simon Wong is a physically beautiful man.

Second-Order Communicative Intention: A second-order communicative intention is an intention regarding first-order communicative intentions. Example: James Madison writes the text of the First Amendment to the Constitution with the second-order intention that the communicative content conveyed by the text be the public meaning of the text.

Second-order communicative intentions play an important role in legal communication. Thus, the drafters of the constitutional text might have had a second-order communicative intention that the text be understood to have the content conveyed by its public meaning and that in cases of divergence between public meaning and their private first-

139 See supra section II.A.3, pp. 48-5 I.

140 Michael S. Moore, Justifying the Natural Law Theory of Constitutional Interpretation, 69 FORDHAM L. REV. 2087, 2096 (2001); see also Adrian Vermeule, Judicial History, ro8 YALE L.J. I3II, I323 (I999) ("On some versions of intentionalism, interpreters are bound not only by the lawmakers' substantive intention to enact rules with certain content, but also by their secondorder intentions about how the rules are to be interpreted."). 
order communicative intentions, the public meaning should prevail. Likewise, the drafters of a statute may have a second-order communicative intention that the text of the statute be understood to have its plain meaning, even if that meaning differs from the drafters own firstorder communicative intentions.

The distinction between first- and second-order communicative intentions operates in the context of contractual communication. For example, the parties to the EEI Master Contract might intend that the agreement have the communicative content intended by the Drafting Committee, even if that content differs from the content assumed by one or even all of the parties to a contract modeled on the Master Contract. In this case, the second-order communicative intentions of the parties would point to Reasonably Accessible Meaning as the intended meaning. All would be well if the parties' first-order communicative intentions mesh with their second-order communicative intentions, but in cases of divergence the law will have to choose. Moreover, the parties might actually express a second-order communicative intention in the agreement itself. For example, the EEI Master Contract might have included an "interpretation clause" 141 specifying that in the case of disagreement over the meaning of the text the communicative intentions of the drafters would govern.

So far as I can tell, Kar and Radin elide the questions raised by "interpretive intent" or "second-order communicative intentions," but Shared Meaning Analysis seems to take a stand on the second-order question as to which communicative intentions should govern. Or perhaps Kar and Radin take more than one stand, shifting from meaning that was actually shared to the meaning that would have been shared if the parties had communicated in the way that would have been most consistent with the maxims. In either case, it is at least possible that the second-order communicative intentions of the parties to a contract would conflict with Shared Meaning Analysis. I am not sure how Kar and Radin would deal with such cases, but I would like to know.

\section{E. The Implications of Shared Meaning Analysis for the Interpretation of Contractual Communication}

We are now in a position to appreciate the relationship between the general account of legal communication that was developed in Part I and Kar and Radin's shared meaning account of contractual communication. That relationship is complex. On the one hand, we need to consider Kar and Radin's three distinct definitions of shared meaning. ${ }^{142}$ On the other hand, we need to account for several features of legal

141 See Uri Benoliel, The Interpretation of Commercial Contracts: An Empirical Study, 69 ALA. L. REV. 469, 480 (20I7) (discussing "merger clauses" as a type of "interpretation clause").

142 See supra section II.B.3, pp. 56-58. I now turn to Kar and Radin's explication of the idea of "shared meaning." 
communication, including (I) the distinction between speaker's meaning and sentence meaning, (2) the semantic and pragmatic mechanisms by which communicative content is conveyed, (3) the limited role of the maxims as rules of thumb, (4) the distinction between first-order and second-order communicative intentions, and (5) the distinction between cooperative and strategic legal communication. And we must bear in mind the interpretation-construction distinction which highlights the difference between the meaning of contractual provisions and their legal effect.

On the surface, Kar and Radin's approach seems to offer a simple and powerful theory of contract interpretation. Readers might believe that the application of Shared Meaning Analysis enables us to identify the "true meaning" of a written contract. We run the written contract through the oral-conversation thought experiment, which then enables us to identify the Maxim Maximizing Meaning (the meaning that is most consistent with the Gricean maxims of conversation). But appearances are deceiving. Application of Kar and Radin's framework can result in content that is different from both the actually shared meaning of the parties and the meaning that was not actually shared by them but was reasonably accessible to them.

Consider the following examples of divergence:

Cases in which the parties recognize noncooperative (strategic) communication but nonetheless have shared understandings. Example: Party $A$ understands that Party $B$ is trying to pull a fast one, but nonetheless agrees because the strategically motivated language is actually in Party $A$ 's interests.

Cases in which the parties hold shared second-order communicative intentions but divergent first-order communicative contentions. Example: Parties $A$ and $B$ sign a form contract such as the EEI Master Contract with the second-order intention that it be given its drafter's meaning. However, none of the agents of $A$ and $B$ actually read and comprehended some of its provisions, even though the agents of either $A$ or $B$ would have understood all of the provisions if they had read them with the degree of effort that is reasonable under the circumstances.

Cases in which the written agreement is comprehensible to the parties, but the hypothetical oral conversation would not result in shared meaning. Example: The written contract is long and as a result there were pragmatic enrichments (such as implicitures and presuppositions) that would be cognitively accessible to a careful reader (such as a lawyer doing due diligence) but would not be accessible in an oral conversation.

These examples bring out the reasons for rejecting the idea that Shared Meaning Analysis provides a reliable method of contract interpretation that yields the true meaning that a written contract had for the parties. A more accurate way of characterizing Shared Meaning 
Analysis is that it is a method of contract construction that yields legally enforceable contract provisions that may differ in systematic ways from the meanings upon which the relevant first- and/or second-order communicative intentions of the parties converged.

\section{Metalinguistic CONTESTATION: "CONTRACT" AND "PSEUDO-CONTRACT"}

One more topic before I close. Kar and Radin distinguish between "contract" and "pseudo-contract." As they understand it, "the distinction between shared meaning (contract) and meaning that is not shared (pseudo-contract)" marks the difference between two fundamentally different categories. ${ }^{143}$ They argue that scholars and courts have failed to appreciate the significance of this basic conceptual distinction because of what they call a "paradigm slip":

We will describe the result of this process as an unconscious or undiagnosed "paradigm slip." In an unconscious paradigm slip, each small step in application aims to preserve the purposes, basic concepts, and coherence of a body of doctrine, but the overall result is a largely unintended and more fundamental change in the meanings and functions of its core concepts. As a result of a largely unconscious paradigm slip in contract law, many courts and scholars now assume that all boilerplate text contributes "terms" to a "contract" in largely unproblematic ways akin to the simpler uses of language to form contracts in 1883 . They assume that pseudo-contractual text should be enforced as "contract" with minimal requirements of "assent," unless there is some standard contract law obstacle to enforcement arising from something like illegality or unconscionability. This is to treat pseudocontract as contract without adequate reflection. A major noncontractual intrusion into the traditional sphere of contract law and modern market activity has gone largely unrecognized; or, at least, the full depths and problematic nature of the intervention have escaped widespread notice. ${ }^{144}$

Thus, Kar and Radin would restrict the proper use of the word "contract" and associated terms like "contractual" and "contracting" to agreements reached on the basis of shared meaning. ${ }^{145}$ Without shared meaning there is no contract, although there might be a pseudocontract. ${ }^{146}$ The terms of contracts are determined by shared meaning, although other terms might create additional pseudo-contractual obligations. ${ }^{147}$

What kind of move are Kar and Radin making? Why do they believe that the distinction between "contract" and "pseudo-contract" is

\footnotetext{
143 Kar \& Radin, supra note I, at I I 66.

$144 I d$. at I I 42 (footnote omitted).

145 See id. at I I40, I2 I4.

146 Id. at I I 55 .

147 Id.
} 
important? Why should we resist the "paradigm slip"? One important angle on these questions is provided by the distinction between "words" and concepts. ${ }^{148}$ "Contract" is a word, as are associated words and phrases like "contractual assent" or "contract terms." The word "contract" has an ordinary meaning in American English, and it may well have a more specialized and nuanced meaning in the linguistic subcommunity of lawyers and judges. But the word "contract" represents a concept that could be expressed in other words. For example, the English word "contract" is translated as "Contrat" in French, ${ }^{149}$ "Vertrag" in German, ${ }^{150}$ and "mkataba" in Swahili. ${ }^{151}$ The word "contract" is used to convey the concept contract.

It might seem that Kar and Radin are merely quibbling about definitions, but I do not believe that the real thrust of their argument is about the meaning of the word "contract." If that were their concern, then we should be able to test their claim against the linguistic evidence. The conventional semantic meaning of the word "contract" is a function of patterns of usage, ${ }^{152}$ but Kar and Radin themselves observe that paradigm slip has resulted from the extension of the word "contract" to agreements without shared meaning, which they call "pseudocontracts." 153 In other words, current usage (after the paradigm slip) disfavors their proposed definition. For this reason, I think that the heart of Kar and Radin's claim is conceptual rather than terminological.

Kar and Radin believe that the concept of contract is being misused, but it is unclear why. They might believe that contract has an essence. ${ }^{154}$ Natural kind terms like "gold" represent concepts that have an essence provided by natural science: for something to be gold, it must have the atomic structure of gold. ${ }^{155}$ Moore has argued that concepts employed by the law, which he calls "functional kinds," and might also be called "moral kinds," have essences which can be investigated by legal

148 See supra section I.B.3(a), pp. 40-42.

149 French Translation of "Contract," COLLINS, https://www.collinsdictionary.com/ dictionary/english-french/contract [https://perma.cc/T4 YR-NBC 5 ].

150 German Translation of "Contract," COLLINS, https://www.collinsdictionary.com/ dictionary/english-german/contract [https://perma.cc/2JJB-EECJ].

151 ONLINE SWAHILI - ENGLISH DICTIONARY, https://africanlanguages.com/swahili [https://perma.cc/BB 5 C-Z $\left.{ }_{9} \mathrm{WJ}\right]$ (search "contract").

152 John F. MANNing \& Matthew C. Stephenson, Legislation and Regulation I 47 ( $3 \mathrm{~d}$ ed. 20I7). The technical meaning of "contract" is a function of patterns of usage in a linguistic subcommunity, for example, patterns of usage among lawyers, judges, and legal scholars. See id. at I5 I (discussing legal terms of art).

153 See Kar \& Radin, supra note I, at I I40.

154 On the idea that natural kinds have an essence, see generally SAUL A. KRIPKE, NAMING and Necessity (I980); 2 Hilary Putnam, The Meaning of "Meaning," in Mind, Language AND REALITY 2 I 5 (I975).

155 See PUtnam, supra note I54, at 223-29. 
theory. ${ }^{156}$ Perhaps, Kar and Radin believe that contract is a functional kind with an essence, although I was unable to find any evidence of such a belief in Pseudo-Contract and Shared Meaning Analysis. ${ }^{157}$

Or perhaps they see the problem through the lens of the conceptconception distinction, famously deployed by John Rawls, ${ }^{158}$ who drew on Essentially Contested Concepts, by the philosopher William Gallie. ${ }^{159}$ Rawls argued that "justice" is a contested concept; he offered his theory, which he called "justice as fairness," as a conception of justice that competes with rival conceptions such as utilitarianism. ${ }^{160}$ Kar and Radin might believe that contract is a contested concept and that Shared Meaning Analysis offers the best conception of that concept. They might then employ the method of reflective equilibrium to demonstrate that Shared Meaning Analysis best accounts for our considered judgments about contract law. So far as I can tell, Kar and Radin do not pursue this strategy in Pseudo-Contract and Shared Meaning Analysis. ${ }^{161}$

Related to the notion that there can be different conceptions of contested concepts is the idea of metalinguistic negotiation. ${ }^{162} \mathrm{~A}$ metalinguistic negotiation involves a dispute over a word or phrase and its associated concept. One way to move forward in the process of metalinguistic negotiation is to agree on standards of conceptual ethics. For example, we might argue that in the context of legal theory, the concept of contract ought to be sufficiently broad to account for disagreements among contract theorists about the best normative account of contract law. It might be argued that an attempt to tie the concept of contract to a particular normative theory involves an illicit attempt to leverage a metalinguistic proposal into a substantive victory in the normative debate. If $\mathrm{Kar}$ and Radin were attempting to make this move, it might be suggested that the attempt to relegate other normative theories of contract to the realm of pseudo-contract fails to preserve the

\footnotetext{
156 See Michael S. Moore, Law as a Functional Kind, in NATURAL Law TheOry I88, 2 I3I 7 (Robert P. George ed., I992).

157 See generally Kar \& Radin, supra note I.

158 JOHn RAWls, The Idea of an Overlapping Consensus, in COLlected PAPERS 42 I (Samuel Freeman ed., I999).

159 W.B. Gallie, Essentially Contested Concepts, 56 Proc. Aristotelian SoC'Y i67 (I956).

160 See generally JOHN RAWLs, A TheORY OF JUSTICE (I97I).

161 See generally Kar \& Radin, supra note I.

162 For explication of the idea of metalinguistic negotiation, see generally David Plunkett \& Tim Sundell, Antipositivist Arguments from Legal Thought and Talk: The Metalinguistic Response, in PRAGMatism, LaW, AND Language 56, 56-75 (Graham Hubbs \& Douglas Lind eds., 2014); David Plunkett \& Tim Sundell, Disagreement and the Semantics of Normative and Evaluative Terms, I3 Philosophers' Imprint I, 3 (2013); and David Plunkett \& Timothy Sundell, Dworkin's Interpretivism and the Pragmatics of Legal Disputes, I9 LEGAL THEORY 242, 248 (20I3); and also see Lawrence B. Solum, Metalinguistic Negotiation, LEGAL THEORY LeXICON (Nov. II, 20I8), http://lsolum.typepad.com/legal_theory_lexicon/20I 7/04/legal-theory-lexicon-075metalinguistic-negotiation.html [https://perma.cc/VC $9 \mathrm{~K}-\mathrm{S} 6 \mathrm{SK}]$.
} 
conceptual structure of theoretical debates about the nature and proper function of contract law.

I am not sure about the deep foundations of Kar and Radin's argument that contract should be limited to agreements with shared meaning in their sense and that the rest of what is now called "contract law" should be moved to their newly proposed category of "pseudo-contract." I confess that I am worried about this move. I am worried because of substantive concerns about Kar and Radin's theory of shared meaning. At this point, their theory is innovative, provocative, and challenging, but I am not sure that it is fully baked. My tentative opinion is that their account of shared meaning faces serious challenges on several fronts, including the problem of reconciling what seems to be an emphasis on actually shared communicative content with ideas about counterfactual meanings related to Grice's maxims of conversation. If the best theory of contractual communication incorporates ideas about reasonably accessible communicative content and the distinction between firstorder and second-order communicative intentions, then it would be a mistake to bake Kar and Radin's theory of shared meaning into the concept of contract itself. These considerations push me in the direction of a more capacious account of the concept of contract, one that allows for a greater diversity of views about the best normative theory of contract law.

At this point, some readers may be impatient with the emphasis on metalinguistic and conceptual issues. Readers with a realist bent might make the following point:

I don't give a hoot whether boilerplate agreements are called "contracts" or "pseudo-contracts." You can call them "schmomtracts"163 for all I care. Conceptual niceties may have their place, but the truly important question is whether these agreements are enforceable or not. Tell me what practical difference it makes, and then I can tell you whether or not I buy the argument.

A full reply to this point would require an extended discussion of the value of conceptual clarity and the development of a normative theory of contract law: neither task can be undertaken in this Response. It is not clear that the acceptance of Kar and Radin's argument would result in judicial determination that some boilerplate agreements are unenforceable: the result could be the development of a distinct body of pseudo-contract doctrine. So far as I can tell, Kar and Radin do not advance the claim that all pseudo-contracts should be legally unenforceable, nor do they provide a test for those pseudo-contracts that should be enforced and those that should not.

Although I cannot make the argument on this occasion, I should think that it is clear that at least some agreements with Unshared Actual Meanings that are reasonably accessible to the parties should be legally

163 Inspired by Heidi M. Hurd, Promises Schmomises, 36 LAW \& PHIL. 279 (20I 7). 
enforceable. For example, in Scenario One, the meaning of the EEI Master Contract is reasonably accessible to the parties even though the meaning was not actually shared at the time of contract formation. ${ }^{164}$ But it seems obvious that invalidation of a contract modeled on the Master Contract would upset the expectations of the parties. In complex transactions like those covered by the Master Contract, requiring all the parties to actually understand all the provisions might well be very costly. Requiring parties to negotiate a bespoke alternative to the Master Contract for each and every wholesale electricity-supply transaction would seem to impose obvious and unnecessary costs. Of course, these common-sense observations fall far short of a rigorous argument, but they suggest that the notion of Reasonably Accessible Meanings may do important normative work that cannot be done by Shared Meaning Analysis alone.

\section{CONCLUSION}

Let me end where I started, with high praise for Pseudo-Contract and Shared Meaning Analysis. Although Kar and Radin's article has prompted me to ask a variety of questions and to raise a series of objections, I believe that this is testimony to the importance of their project. Like Kar and Radin, I believe that attention to the philosophy of language and theoretical linguistics is crucially important to progress in legal theory generally and to disputes about interpretation and construction of constitutions, statutes, rules, regulations, and contracts - to start a list that undoubtedly is much longer. Like Kar and Radin, I believe that Paul Grice's theory of meaning is an important starting point, and like them, I believe that Grice's maxims teach important lessons about the ways in which legal communication works.

Unlike Kar and Radin, I am not convinced that Grice's maxims of communication provide the magic key that will unlock the door to the true meanings of legal communications. The maxims are rules of thumb that frequently enable us to communicate more efficiently and effectively, but rules of thumb are not (and should not become) rules of law. The maxims are part of the story but only a part. The full story must include an account of semantic and pragmatic mechanisms, the distinction between first- and second-order communicative intentions, the idea of Reasonably Accessible Meaning, and much else.

But even if Kar and Radin have overestimated the role of the maxims in answering questions about the meaning of contractual communications, Pseudo-Contract and Shared Meaning Analysis is an important landmark in the application of ideas from the philosophy of language and theoretical linguistics to contract theory. Pathbreaking scholarship frequently raises more questions than it answers and starts more debates

164 See supra section II.B.I, p. 53. 
[Vol. I33:23

than it finishes. Kar and Radin are raising the truly important questions, and their work seems likely to start a whole series of debates about the nature of contractual communication.

Recommended Citation: Lawrence B. Solum, Contractual Communication, I33 HARV. L. REV. F. 23 (20I9), https://harvardlawreview.org/20I9/I I/contractual-communication. 